\title{
Nociceptor Beta II, Delta, and Epsilon Isoforms of PKC Differentially Mediate Paclitaxel-Induced Spontaneous and Evoked Pain
}

\author{
Ying He and Zaijie Jim Wang \\ Department of Biopharmaceutical Sciences and Cancer Center, University of Illinois, Chicago, Illinois 60612
}

As one of the most effective and frequently used chemotherapeutic agents, paclitaxel produces peripheral neuropathy (paclitaxelinduced peripheral neuropathy or PIPN) that negatively affects chemotherapy and persists after cancer therapy. The mechanisms underlying this dose-limiting side effect remain to be fully elucidated. This study aimed to investigate the role of nociceptor protein kinase C (PKC) isoforms in PIPN. Employing multiple complementary approaches, we have identified a subset of PKC isoforms, namely $\beta \mathrm{II}, \delta$, and $\epsilon$, were activated by paclitaxel in the isolated primary afferent sensory neurons. Persistent activation of PKC $\beta \mathrm{II}, \mathrm{PKC} \delta$, and $\mathrm{PKC} \epsilon$ was also observed in the dorsal root ganglion neurons after chronic treatment with paclitaxel in a mouse model of PIPN. Isoformselective inhibitors of $\mathrm{PKC} \beta \mathrm{II}, \mathrm{PKC} \delta$, and PKC $\epsilon$ given intrathecally dose-dependently attenuated paclitaxel-induced mechanical allodynia and heat hyperalgesia. Surprisingly, spinal inhibition of $\mathrm{PKC} \beta \mathrm{II}$ and $\mathrm{PKC} \delta$, but not $\mathrm{PKC} \epsilon$, blocked the spontaneous pain induced by paclitaxel. These data suggest that a subset of nociceptor PKC isoforms differentially contribute to spontaneous and evoked pain in PIPN, although it is not clear whether PKC $\epsilon$ in other regions regulates spontaneous pain in PIPN. The findings can potentially offer new selective targets for pharmacological intervention of PIPN.

Key words: cancer; chemotherapy; pain; protein kinase C; taxane

\section{Introduction}

Originally isolated from the bark of pacific yew tree Taxus brevifolia, paclitaxel is a potent antineoplastic agent used to treat breast, ovarian, lung, head, and neck cancer and advanced forms of Kaposi's sarcoma (Wani et al., 1971; Rowinsky, 1993). By targeting tubulin, paclitaxel stabilizes the microtubule polymer and prevents it from disassembling, resulting in mitosis blockage (Horwitz, 1992). As a highly efficacious anticancer agent, paclitaxel also produces dose-limiting painful neuropathy that negatively affects successful chemotherapy (Lee and Swain, 2006). Patients experience sensory abnormalities such as numbness and tingling, mechanical allodynia, cold allodynia, and ongoing burning pain (Postma et al., 1995). Although paclitaxel-induced peripheral neuropathy (PIPN) is more common with high-dose chemotherapy regimens, severe painful neuropathy also occurs at relatively low doses (Perez et al., 2001; Tulpule et al., 2002) and can persist for months or even years after chemotherapy (Pignata et al., 2006). Currently, no treatment can effectively prevent or treat PIPN; therefore, understanding its molecular mechanisms may shed light on designing novel therapies for PIPN.

\footnotetext{
Received April 17, 2014; revised Jan. 16, 2015; accepted Feb. 5, 2015.

Author contributions: Y.H. and Z.J.W. designed research; Y.H. and Z.J.W. performed research; Y.H. and Z.J.W. analyzed data; Y.H. and Z.J.W. wrote the paper.

The authors declare no competing financial interests.

Correspondence should be addressed to Zaijie Jim Wang, PhD, Department of Biopharmaceutical Sciences and Cancer Center, University of Illinois (MC865), 833 S Wood St, Chicago, IL 60612. E-mail: zjwang@uic.edu.

DOI:10.1523/JNEUROSCI.1580-14.2015

Copyright $\odot 2015$ the authors $\quad 0270-6474 / 15 / 354614-12 \$ 15.00 / 0$
}

In this study, we considered the possibility that PIPN is mediated by specific cellular mechanisms that are different from the drug's antineoplastic action. It has become increasingly apparent that protein kinases, such as protein kinase $\mathrm{C}$ (PKC), and $\mathrm{A}$ (PKA), constitute important regulatory mechanisms in nociceptors. Particularly, the fundamental role of $\mathrm{PKC}$ in regulating neuronal plasticity and pain transmission has been implicated. PKC comprises multiple isoforms with distinct kinetics and functional characteristics. Based on their activation requirements, they are classified into three subfamilies: conventional, novel, and atypical (Nishizuka, 1995). In a seminal study, not only was a model of PIPN established in rats, but PKC $\epsilon$ and PKA were proposed as critical second messengers mediating paclitaxel-induced hyperalgesia (Dina et al., 2001). More recently, we independently confirmed these findings in a mouse model of PIPN by spinal inhibition of PKC $\epsilon$ and PKA (Chen et al., 2011). These studies, however, led to additional questions on the potential roles of other PKC informs in paclitaxel-induced hyperalgesia. Therefore, comprehensive elucidation of the functional involvement of all nociceptor $\mathrm{PKC}$ isoforms in PIPN became the aim of the present study.

Preclinical pain studies have almost exclusively focused on evoked hypersensitivity, whereas a major complaint of patients with chemotherapy-induced peripheral neuropathy is the presence of spontaneous or ongoing pain (Einzig et al., 1992; Dougherty et al., 2004). This discrepancy may be a reason for the poor translation of basic research findings to clinically useful therapies (Borsook et al., 2014). We recently validated a method of employing negative reinforcement to study spontaneous pain in mice 
(He et al., 2012; Corder et al., 2013) and applied the conditioned place preference $(\mathrm{CPP})$ paradigm in the present study to characterize spontaneous pain in PIPN.

By profiling the activation of all PKC isoforms in sensory neurons, we identified a subset of nociceptor PKC isoforms, specifically $\mathrm{PKC} \beta \mathrm{II}, \mathrm{PKC} \delta$, and $\mathrm{PKC} \epsilon$, that were responsive to paclitaxel. These PKC isoforms were further found to differentially mediate paclitaxel-induced spontaneous pain and evoked hypersensitivity to mechanical and thermal stimuli.

\section{Materials and Methods}

Materials. Lidocaine $\mathrm{HCl}$ (2\%) was from Hospira. Paclitaxel and other chemicals were purchased from Sigma-Aldrich. Myristoylated peptide inhibitors of PKC isoforms [PKC $\alpha$ : (FARKGALRQ), PKC $\beta I$ : (KLFIMN), PKC $\beta I I$ : (QEVIRN), PKC $\delta$ : (SFNSYELGSL), PKC $\epsilon$ : (EAVSLKPT), PKC $\theta$ : (LHQRRGAIKQAKVHHVKC) and PKC : (SIYRRGARRWRKL)] were synthesized according to previously published sequences (Chen et al., 2001; Stebbins and Mochly-Rosen, 2001; Smith et al., 2007) and verified by mass spectrometry by the Protein Research Laboratory, University of Illinois at Chicago (Chen et al., 2011).

Cell culture. Adult DRG cell cultures were prepared as described previously (Lindsay, 1988; Burkey et al., 2004). Briefly, male Sprague Dawley rats (150-175 g; Charles River Laboratories) were euthanized by $\mathrm{CO}_{2}$ asphyxiation. DRGs were collected from the entire spinal column, incubated in F-12 medium containing $0.125 \%$ collagenase for $2 \mathrm{~h}$ in $5 \% \mathrm{CO}_{2}$ at $37^{\circ} \mathrm{C}$, and mechanically dissociated. Approximately 15,000 cells were plated into each well (16 mm diameter) of 24 -well culture plates or 4000 cells in each chamber of eight-chamber Lab-Tek chamber slides. All culture dishes were precoated with poly-D-lysine and laminin. The cells were maintained in F-12 medium supplemented with $10 \%$ horse serum, $2 \mathrm{~mm}$ glutamine, $100 \mu \mathrm{g} / \mathrm{ml}$ normocin $\mathrm{O}, 50 \mu \mathrm{g} / \mathrm{ml}$ penicillin, $50 \mu \mathrm{g} / \mathrm{ml}$ streptomycin, $50 \mu \mathrm{M} 5$-fluoro-2' -deoxyuridine, $150 \mu \mathrm{M}$ uridine, and 250 $\mathrm{ng} / \mathrm{ml} \mathrm{NGF}$ in $5 \% \mathrm{CO}_{2}$ at $37^{\circ} \mathrm{C}$. Growth medium was changed every other day.

Animals. Male ICR mice (25-30 g; Charles River Laboratories) were maintained on a 14/10 h light/dark cycle (5:00 A.M. on/7:00 pm off) with food and water provided ad libitum before experimental procedures. All animal experiments were performed during the light cycle. Mice were randomly divided into experimental groups according to a computergenerated randomization list. All procedures were performed in accordance with the International Association for the Study of Pain and the National Institutes of Health's Guide for the Care and Use of Laboratory Animals after approval by the University of Illinois Institutional Animal Care and Use Committee. Experiments were conducted with treatments blinded in the behavioral studies.

CGRP release assay. Rat DRG cells were maintained in culture for $10 \mathrm{~d}$ before release studies. CGRP release was determined by incubating cells in HEPES buffer consisting of $25 \mathrm{~mm}$ HEPES, $135 \mathrm{~mm} \mathrm{NaC1}, 3.5 \mathrm{~mm}$ $\mathrm{KC1}, 2.5 \mathrm{mM} \mathrm{CaCl}_{2}, 1 \mathrm{~mm} \mathrm{MgC1}{ }_{2}, 3.3 \mathrm{~mm}$ D-glucose, $0.1 \mathrm{~mm}$ ascorbic acid, $0.02 \mathrm{~mm}$ bacitracin, $1 \mu \mathrm{M}$ phosphoramidon, and $0.1 \%$ bovine serum albumin, $\mathrm{pH} 7.4$, and maintained at $37^{\circ} \mathrm{C}$ in the presence or absence of paclitaxel for $10 \mathrm{~min}$. In inhibitory experiments, cells were exposed to individual PKC inhibitors for $10 \mathrm{~min}$ before and throughout the $10 \mathrm{~min}$ incubation for release assay. The content of CGRP in the release buffer was determined using an enzyme immunoassay (Cayman Chemical).

Immunofluorescent analysis. For immunofluorescent analysis of translocation, cells or tissues were fixed and permeabilized after paclitaxel treatments and incubated with primary antibodies of individual PKC isoforms (1:500; Santa Cruz Biotechnology), followed by another incubation with Alexa Fluor 488-labeled or Alexa Fluor 594-labeled secondary anti-goat or anti-rabbit IgG antibodies (1:500; Invitrogen). For IB4 colabeling, cells were also incubated with FITC-labeled IB4 $(10 \mathrm{mg} / \mathrm{ml}$; Sigma). For TRPV1 colabeling, cells were first labeled with TRPV1 antibody (1:20,000; Neuromics) using Tyramide Signal Amplification Kits (Invitrogen) before staining with PKC antibodies. Images were captured using a Zeiss LSM 510 confocal microscope.

Western blot analysis. Western blot analysis was performed as described previously (He et al., 2010) using the antibody against individual
PKC isoforms (1:1000; Santa Cruz Biotechnology). The expression of $\beta$-actin was similarly determined from the same blots using a monoclonal antibody (1:10,000; Sigma). After incubation with HRP-conjugated secondary antibodies, enhanced chemiluminescence signals were captured by a ChemiDoc imaging system and analyzed using the Quantity One program (Bio-Rad).

Paclitaxel-induced painful neuropathy and drug administration. Paclitaxel-induced painful neuropathy was produced according to a previously published method with some modifications (Chen et al., 2011). Mice received paclitaxel $(1.0 \mathrm{mg} / \mathrm{kg}$ dissolved in DMSO and serially diluted in saline; final DMSO concentration is $4 \%$, i.p.) every $2 \mathrm{~d}$ (days 0,2 , 4, and 6; see Fig. 5A). Control mice received equal volume and number of vehicle (saline containing 4\% DMSO) injections. After PIPN was well established (Chen et al., 2011), PKC isoform inhibitors were administered intrathecally on day 26 (see Fig. $5 A$ ) in a volume of $5 \mu$ l by percutaneous puncture through the L5-L6 intervertebral space (Hylden and Wilcox, 1980; Chen et al., 2010).

Assessment of mechanical and thermal sensitivity. Mechanical sensitivity was assessed with von Frey filaments (Chen et al., 2010). Mice were placed in individual Plexiglas containers with wire mesh platform and calibrated von Frey filaments (Stoelting) were used to press upward to the midplantar surface of the left hindpaw for $5 \mathrm{~s}$ or until a withdrawal response occurred. Using the "up-down" algorithm, 50\% probability of paw withdrawal threshold was determined.

Sensitivity to the heat stimulus was determined by paw withdrawal latency to radiant heat using a plantar tester (UGO BASILE Model 7372; Hargreaves et al., 1988; Chen et al., 2010). Mice were placed in clear plastic chambers with a glass floor. Radiant heat stimulation was applied to the center of the planter surface of the left hindpaw and the latency to paw withdrawal was recorded. A cutoff time of $20 \mathrm{~s}$ was applied to avoid tissue damage.

$C P P$. Spontaneous pain was measured using the CPP paradigm as described previously (He et al., 2012). Mice were exposed to the CPP apparatus (San Diego Instruments) with full access to all chambers for 3 consecutive days ( $30 \mathrm{~min} / \mathrm{d}$, days $23-25$; see Fig. $5 \mathrm{~A}$ ). A preconditioning bias test was performed to exclude mice that had a preexisting chamber bias on day 25. On conditioning day (day 26), mice first received vehicle control ( $5 \mu$ l of saline, i.t.) paired with a randomly chosen chamber in the morning and, $4 \mathrm{~h}$ later, either lidocaine $(0.04 \%$ in $5 \mu \mathrm{l}$ of saline, i.t.) or a PKC isoform inhibitor (in $5 \mu$ l of saline, i.t.) paired with the other chamber. During conditioning, mice were allowed to stay only in the paired chamber without access to other chambers for $30 \mathrm{~min}$ immediately after saline or drug injection. On the following day, $20 \mathrm{~h}$ after the afternoon pairing, mice were placed in the middle chamber of the CPP box with all doors open to have free access to all chambers. Movement and duration of time each mouse spent in each chamber were recorded for $15 \mathrm{~min}$ for offline analysis of chamber preference. Difference scores were calculated as (test time-preconditioning time) spent in the drug chamber.

Data analysis. All data are expressed as mean \pm SEM. The statistical comparisons among multiple groups were analyzed by ANOVA, followed by Dunnett's post hoc $t$ test. Two-way ANOVA (pairing vs treatment) was applied followed by Bonferroni post hoc test to analyze CPP data. Difference scores were analyzed using paired $t$ test comparing the differences between test time and preconditioning time in each chamber. Statistical significance was established at the $95 \%$ confidence limit.

\section{Results}

\section{Activation of specific PKC isoforms by paclitaxel in primary} afferent sensory neurons

Primary afferent sensory neurons are the gateway by which sensory information from peripheral tissues is transmitted to the spinal cord and brain (Julius and Basbaum, 2001; Reichling et al., 2013), serving as an ideal model system for studying the molecular mechanisms in nociceptors that are activated by paclitaxel. Previously, we have found that paclitaxel, at low nanomolar concentrations, excited dorsal root ganglion (DRG) neurons by triggering intercellular $\mathrm{Ca}^{2+}$ signaling (He and Wang, 2010). The $\mathrm{Ca}^{2+}$ signals triggered by paclitaxel are able to function as a sec- 

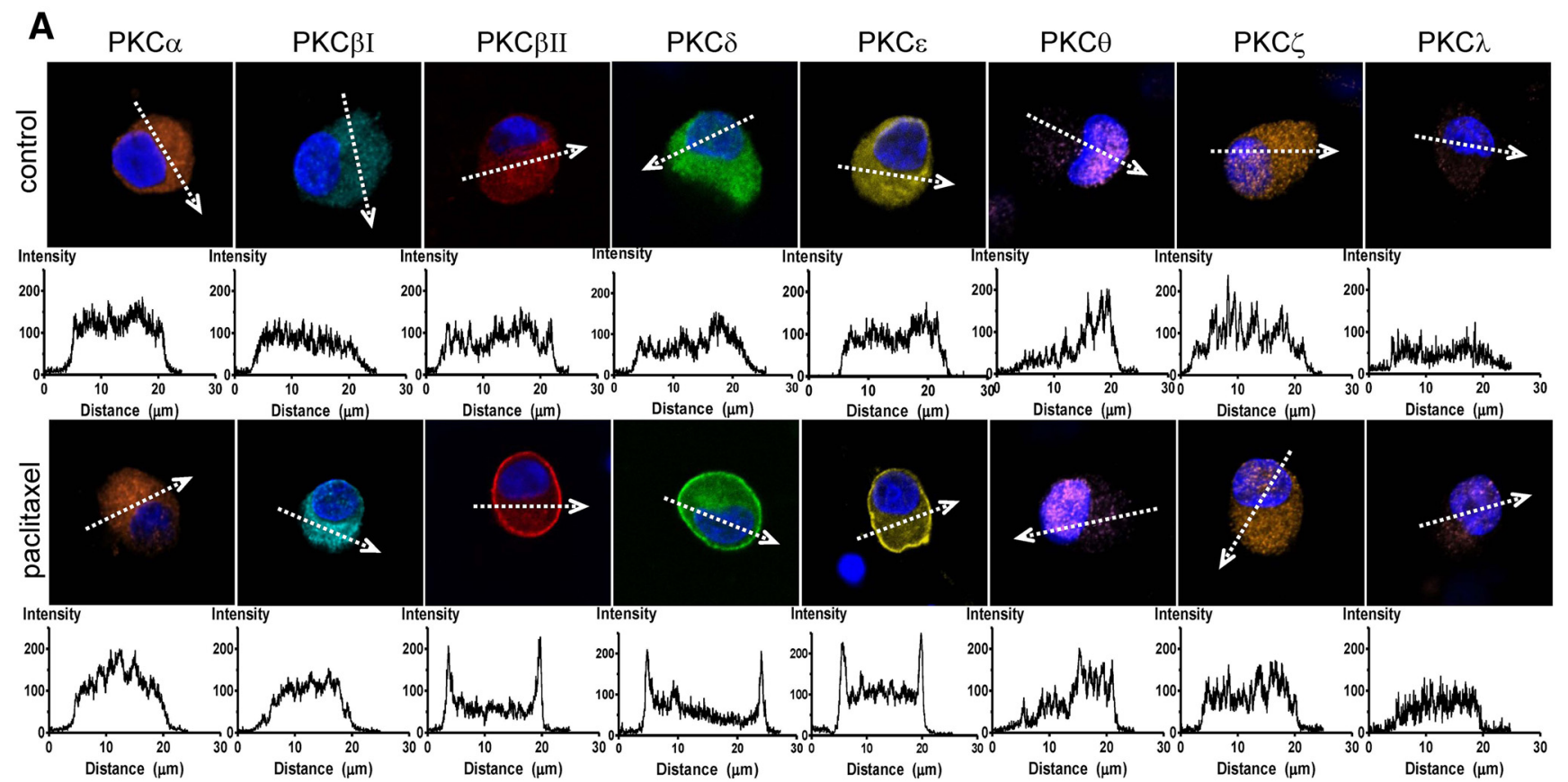

B

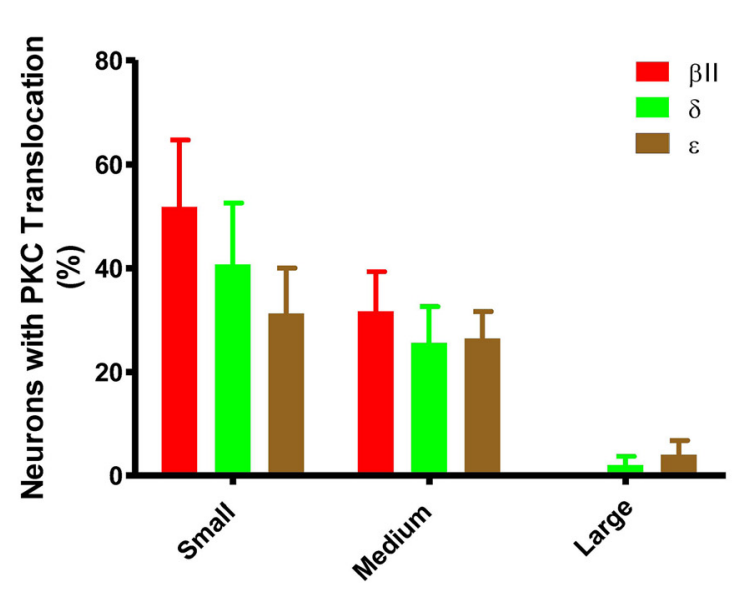

C

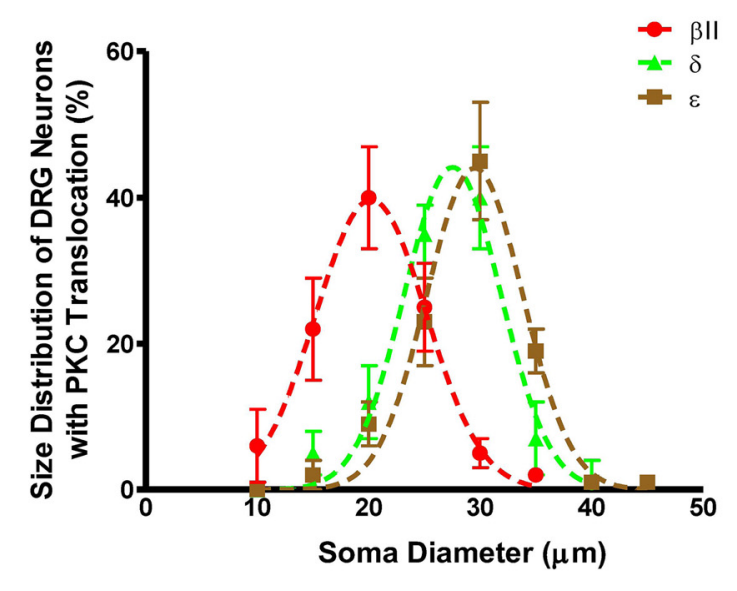

Size of DRG Neuron

Figure 1. $A$, Paclitaxel-induced plasma membrane translocation of PKC isoforms in DRG neurons. Among the PKC isoforms expressed in rat DRG neurons, PKC $\beta$ III, PKC $\delta$, and PKC $\epsilon$, but not other isoforms, showed significant plasma membrane translocation, indicative of their activation upon paclitaxel treatment (10 nm, $1 \mathrm{~h})$. The fluorescent intensity of each PKC isoform across the cell (indicated by the arrow) is illustrated in the chart. $\boldsymbol{B}$, Quantitative analysis of paclitaxel-treated DRG neurons with PKC translocation. The soma area of DRG neurons was measured to determine the percentage of sensory neurons within each size classification (small: $<600 \mu \mathrm{m}^{2}$, medium: $600-1200 \mu \mathrm{m}^{2}$, or large: $>1200 \mu \mathrm{m}^{2}$; Peters et al., 2007) that had translocation of each PKC isoform (PKC $\beta \|$, PKC $\delta$, and PKC $\epsilon$ ). C, Size distribution of sensory neurons with PKC isoform (PKC $\beta \|$, PKC $\delta$, and PKC $\epsilon$ ) translocation by soma diameter. Six hundred neurons were examined for each isoform.

ond messenger that mediates a wide range of cellular responses, including stimulating the activity of $\mathrm{Ca}^{2+}$-dependent protein kinases, such as PKC isoforms. We first screened the expression of the entire family of PKC isoforms and found that eight PKC isoforms have immunoreactivity in the DRG sensory neurons (Fig. 1A, top).

We examined the activation of individual PKC isoforms by monitoring their plasma membrane translocation after paclitaxel treatment (Hucho et al., 2005; Amadesi et al., 2006). Of the conventional PKC isoforms expressed in DRG neurons ( $\alpha, \beta \mathrm{I}, \beta \mathrm{II})$, only PKC $\beta$ II was translocated from the cytosol to the plasma membrane by paclitaxel. Immunofluorescent analysis showed that paclitaxel $(10 \mathrm{nM}, 1 \mathrm{~h})$ induced a recruitment of PKC $\beta \mathrm{II}$ from the cytosol to the plasma membrane of the soma, indicative of its activation, in 498 of 600 (83\%) cells imaged (50 cells/slide,
12 slides; Fig. 1). In the class of novel PKC isoforms (PKC $\delta$, $\mathrm{PKC} \epsilon$, and $\mathrm{PKC} \theta$ ), both $\mathrm{PKC} \delta$ and $\mathrm{PKC} \epsilon$ were enriched onto the membrane domain of the soma in 408/600 (68\%) and 372/600 (62\%) cells examined, respectively, after exposure to paclitaxel. Interestingly, immunoreactivity of $\mathrm{PKC} \theta$ was primarily found in the nucleus in sensory neurons, though it was not found to translocate toward the plasma membrane by paclitaxel. Paclitaxel did not cause redistribution of the atypical PKC isoforms (PKC $\zeta$ and PKC $\lambda$ ).

Translocation of all three PKC isoforms occurred mostly in the small- to medium-diameter neurons (Fig. $1 B, C$ ). The average size of cells showing paclitaxel-induced PKC $\beta$ II translocation was even smaller than those showing translocation of $\mathrm{PKC} \delta$ and PKC $\epsilon$, with almost no translocation in large-diameter neurons. Moreover, we found $\mathrm{PKC} \beta \mathrm{II}, \mathrm{PKC} \delta$, and $\mathrm{PKC} \epsilon$ translocation 
A

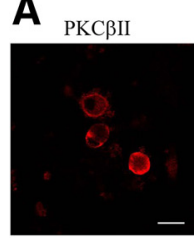

PKC 8

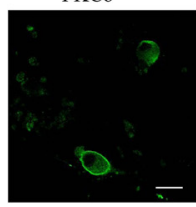

$\mathrm{PKC} \varepsilon$

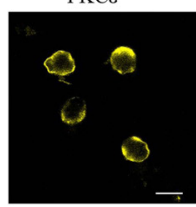

IB4

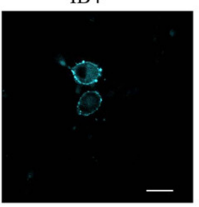

IB4

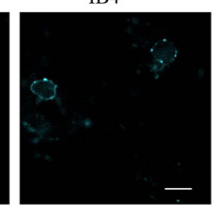

IB4

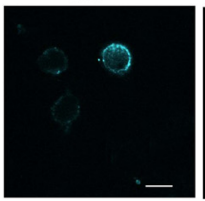

Overlay

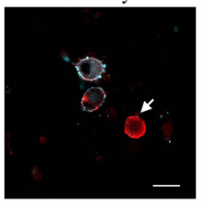

Overlay

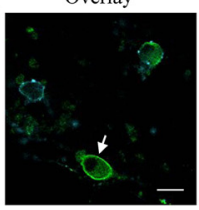

Overlay

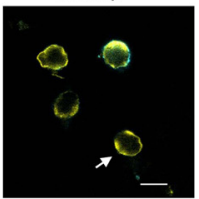

B

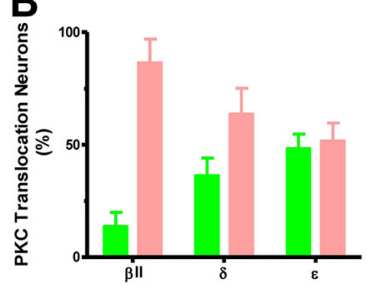

C

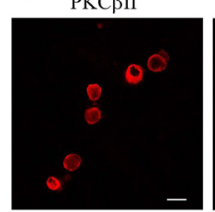

PKC $\delta$

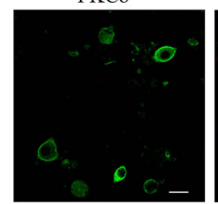

PKCE

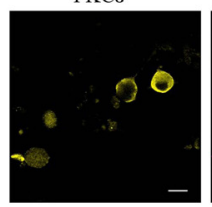

TRPV1

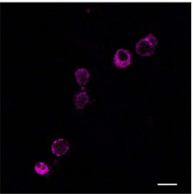

TRPV1

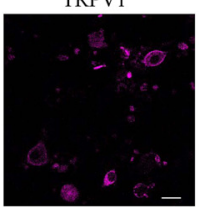

TRPV1

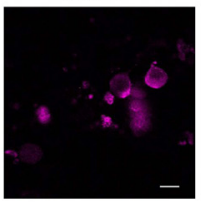

Overlay

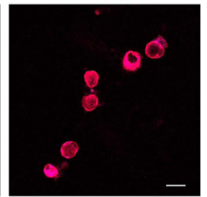

Overlay

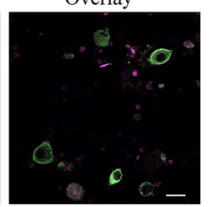

Overlay

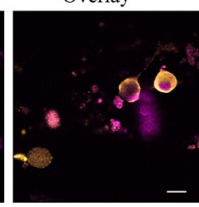

Figure 2. $A$, Translocation of PKC isoform (PKC $\beta I I, P K C ~ \delta$, or PKC $\epsilon$ ) occurred in both IB4-positive and IB4-negative sensory neurons. Paclitaxel-treated DRG neurons were colabeled with PKC isoform PKC $\beta$ II, PKC $\delta$, or PKC $\epsilon$ and IB4-FITC. $\boldsymbol{B}$, Quantitative analysis of PKC translocation DRG neurons within IB4-positive and IB4-negative population ( $n=300$ neurons for each isoform). $\boldsymbol{C}$, Translocation of PKC $\beta \|$ I, PKC $\delta$, or PKC $\epsilon$ occurred in sensory neurons expressing TRPV1. Paclitaxel-treated DRG neurons were costained with PKC isoform (PKC $\beta \|$, PKC $\delta$, or PKC $\epsilon$ ) and TRPV1. Scale bar, $20 \mu \mathrm{m}$.

occurred in both IB4-positive and IB4-negative cells (Fig. 2A), although the proportions of cell population differed. PKC $\beta$ II translocation was found mostly in the IB4-negative cells, whereas $\mathrm{PKC} \epsilon$ translocation occurred with equal frequency in IB4-positive and IB4-negative cells. PKC $\delta$ translocation showed a preference for IB4-negative cells (Fig. 2B). Furthermore, all cells with PKC translocation have TRPV1-immunoreactivity (Fig. 2C).

To complement the immunofluorescent approach, we determined the translocation of PKC isoforms by cell fractionation (Fig. 3). Western blot analysis showed that the immunoreactivity of PKC $\beta \mathrm{II}, \mathrm{PKC} \delta$, and $\mathrm{PKC} \epsilon$ was accumulated in the plasma membrane, whereas their expression in the cytosolic portion was reduced after paclitaxel exposure (10 $\mathrm{nm}$ for $60 \mathrm{~min}$ ). In contrast, other PKC isoforms (e.g., PKC $\alpha$ and $\mathrm{PKC} \beta \mathrm{I}$ ) did not show paclitaxel-induced immunoreactivity redistribution between the plasma membrane and the cytosol in DRG cells (Fig. 3). These data confirmed the immunofluorescent translocation findings that paclitaxel induced activation of a subset of $\mathrm{PKC}$ isoforms including $\mathrm{PKC} \beta \mathrm{II}, \mathrm{PKC} \delta$, and $\mathrm{PKC} \epsilon$.

\section{PKC isoform-dependent release of CGRP by paclitaxel}

As a critical step in the initiation and transmission of pain, release of excitatory neuropeptides such as calcitonin gene-related peptide (CGRP) from the primary afferent neurons can serve as a biomarker for sensory neuron activation and is central to the development of persistent pain (Barber and Vasko, 1996). We next examined the causative role of $\mathrm{PKC}$ isoforms in gating CGRP release after paclitaxel treatment. Paclitaxel produced a dose-dependent release of CGRP, with $\mathrm{EC}_{50}$ of $2.9 \pm 1.1 \mathrm{~nm}$ (Fig. $4 A)$. The maximum response ( $\sim 2.6$-fold increase) was reached at a relatively low concentration $(10 \mathrm{nM})$. Intriguingly, inhibitors of $\mathrm{PKC} \beta \mathrm{II}, \mathrm{PKC} \delta$, or $\mathrm{PKC} \epsilon$, but not other isoforms, significantly suppressed paclitaxel-induced CGRP release (Fig. 4B). These data indicated that the specific $\mathrm{PKC}$ isoforms activated by paclitaxel (PKC $\beta$ II, PKC $\delta$, and $\mathrm{PKC} \epsilon$ ) also have functional relevance in modulating CGRP release from DRG neurons.

The inhibitory effects of PKC $\beta \mathrm{II}, \mathrm{PKC} \delta$, and $\mathrm{PKC} \epsilon$ were further studied over a concentration range to construct dose- response curves. Inhibiting these $\mathrm{PKC}$ isoforms yielded different maximum effect $\left(E_{\max }\right)$ on the inhibition of paclitaxel-induced CGRP release, with the following efficacy order: PKC $\beta$ II > $\mathrm{PKC} \delta>\mathrm{PKC} \epsilon$ (Fig. $4 C-F)$.

\section{Persistent activation of specific PKC isoforms in paclitaxel-treated mice}

To substantiate the in vitro finding that specific PKC isoforms were activated in response to paclitaxel treatment, we further evaluated the activation of these isoforms in a mouse model of PIPN in which evoked hypersensitivity to heat, cold, and mechanical stimuli lasted for at least $30 \mathrm{~d}$ (Chen et al., 2011). Mice received repeated administration of paclitaxel every other day for 4 treatments ( $1 \mathrm{mg} / \mathrm{kg}$, i.p., on days 0,2 , 4, and 6; Fig. 5A). On day 26 , after paclitaxel hyperalgesia was well established, DRG tissues were harvested for immunohistochemical analysis of cellular PKC isoform distribution. Prominent plasma membrane translocation of PKC $\beta$ II, PKC $\delta$, and PKC $\epsilon$ was observed in the DRG slides examined (Fig. 5B). PKC $\beta$ II was found to be activated in 255 of $300(85 \%)$ cells imaged ( 20 cells/slide, 5 slides/mouse, 3 mice/group). Similarly, 228/300 (76\%) and 204/300 (68\%) of cells showed profound plasma membrane enrichment of $\mathrm{PKC} \delta$ and $\mathrm{PKC} \epsilon$, respectively. These data indicated that paclitaxel induced persistent activation of nociceptor PKC $\beta I$, $\mathrm{PKC} \delta$, and $\mathrm{PKC} \epsilon$ in the animal model of paclitaxel peripheral neuropathy.

\section{Effective inhibition of $\mathrm{PKC} \beta \mathrm{II}, \mathrm{PKC} \delta$, and $\mathrm{PKC} \epsilon$ in vivo}

To study the functional relevance of these PKC isoforms, we next determined the effects of inhibition of PKC isoforms by intrathecally administering isoform-selective inhibitors of PKC $\beta \mathrm{II}$, PKC $\delta$, or PKC $\epsilon$ (Chen et al., 2001; Stebbins and Mochly-Rosen, 2001; Smith et al., 2007) to paclitaxel-treated mice on day 26 (Fig. $5 A$ ). Membrane translocation of these PKC isoforms in the DRG was dramatically attenuated $30 \mathrm{~min}$ after the administration of PKC isoform-specific inhibitors (Fig. 5B). We measured immunofluorescent densities on the plasma membrane and the cytosol 


$\begin{array}{lllllll}\text { PKC } \alpha & 0 & 1 & 5 & 10 & 30 & 60(\mathrm{~min}) \\ \text { Cytosolic } & & & & & & \end{array}$

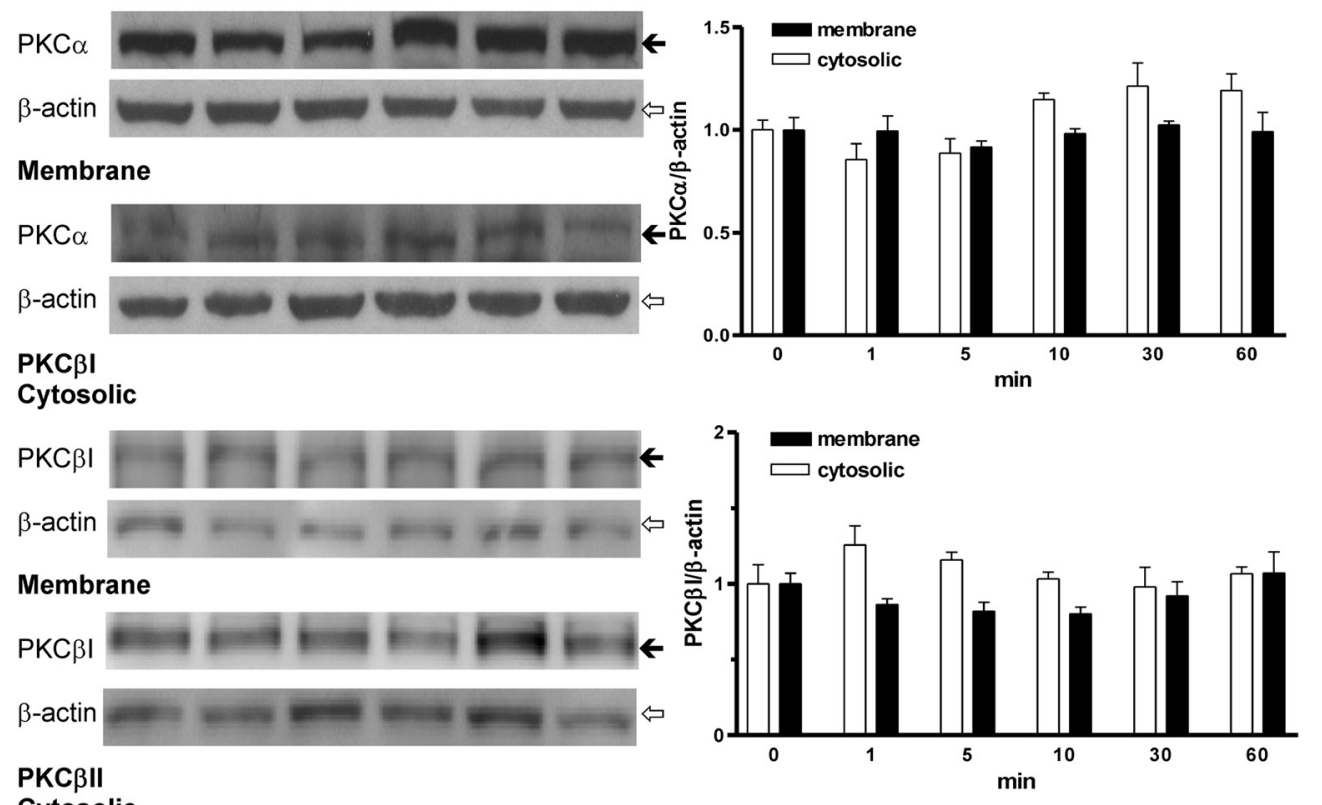

\section{Cytosolic}

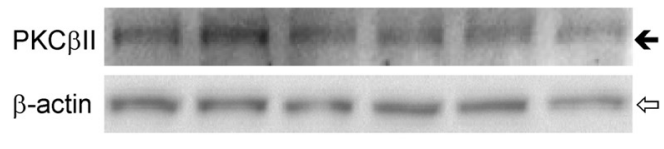

\section{Membrane}

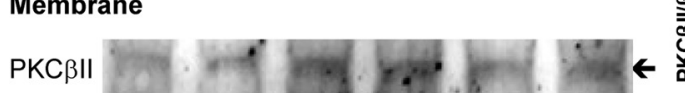

$\beta$-actin

PKC $\delta$

Cytosolic

PKC $\delta$

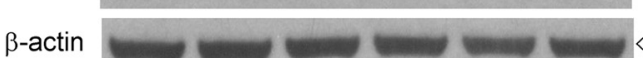

Membrane

PKC $\delta$

$\beta$-actin

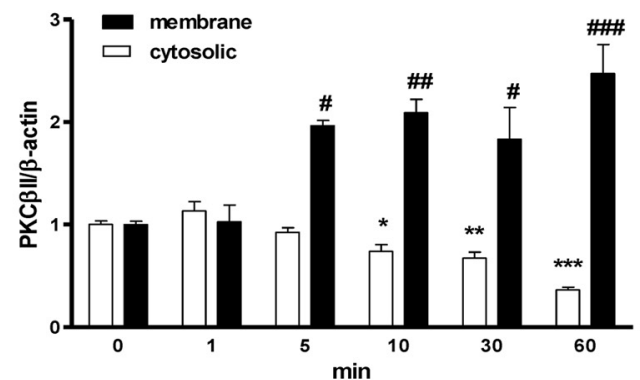

PKC $\varepsilon$

Cytosolic

$\mathrm{PKC} \varepsilon$

$\beta$-actin

\section{Membrane}

$\mathrm{PKC} \varepsilon$

$\beta$-actin
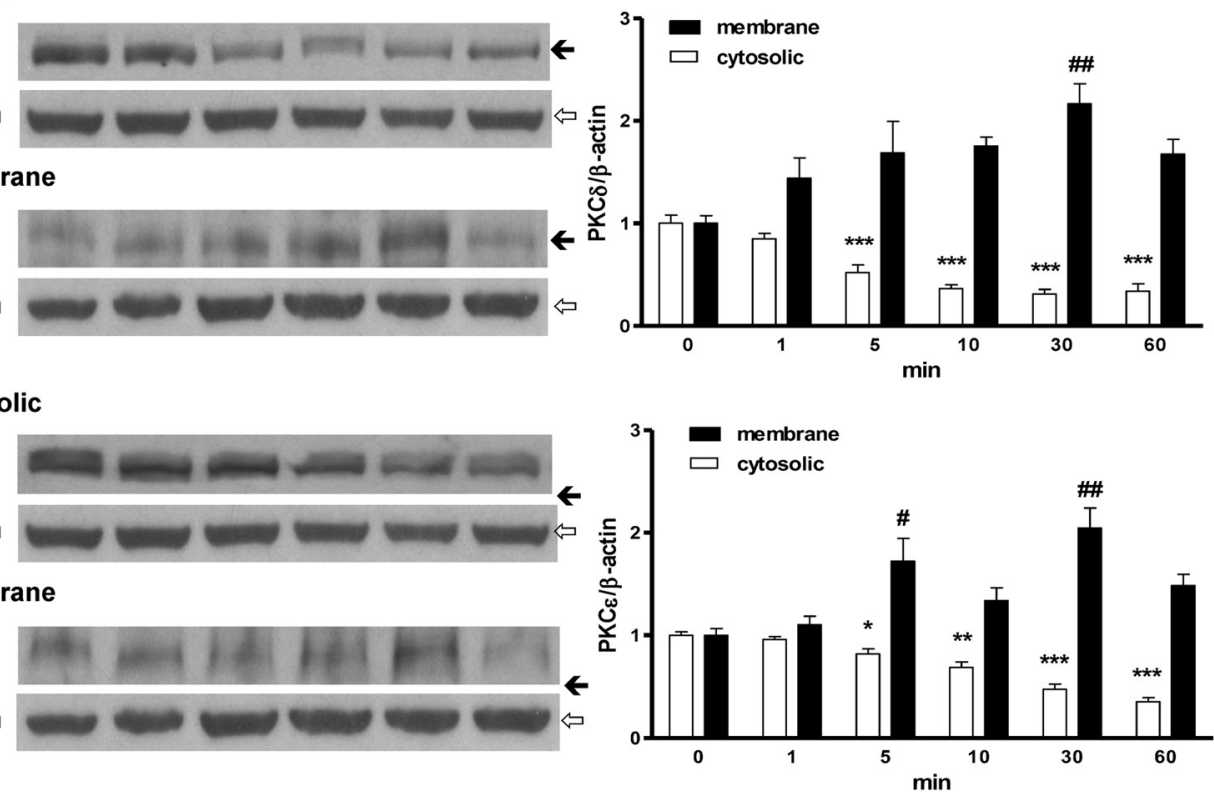

Figure 3. Paclitaxel $(10 \mathrm{~nm}, 1 \mathrm{~h})$ induced-PKC $\beta \|$, PKC $\delta$, and PKC $\epsilon$ translocation from cytosol to plasma membrane as determined by cell fractionation followed by Western blotting analysis in the DRG neurons. ${ }^{*} p<0.05,{ }^{* *} p<0.01,{ }^{* * *} p<0.001$ versus the cytosolic 0 time group; $\# p<0.05$, \#\#p $<0.01$, \#\#\#p $<0.001$ versus the membrane 0 time group $(n=3)$. The molecular weight markers are indicated by $\leftarrow(80 \mathrm{kDa})$ and $\leftarrow(42 \mathrm{kDa})$. 
A

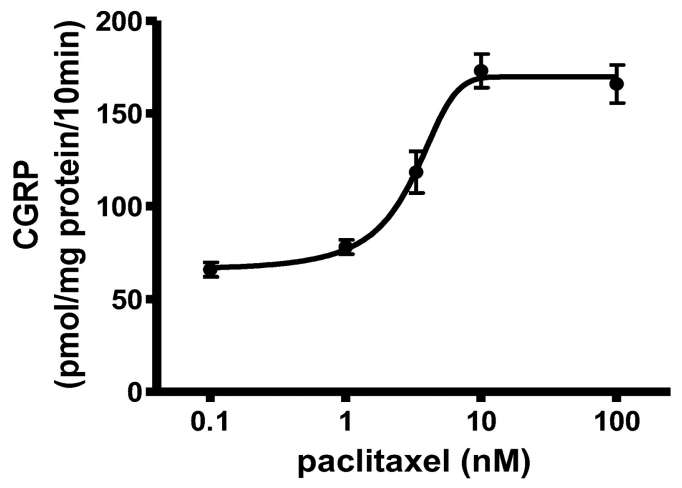

C

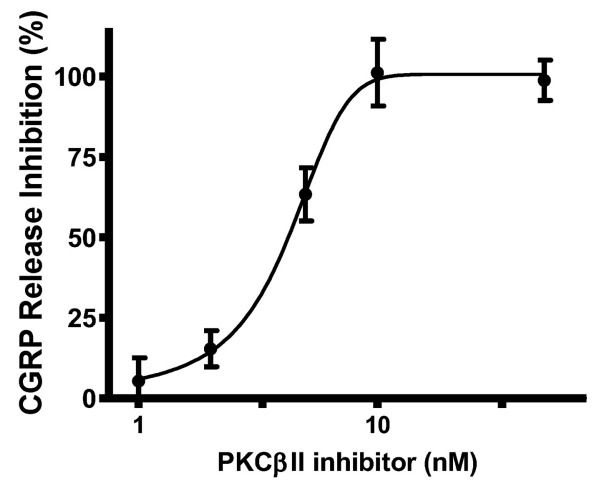

E

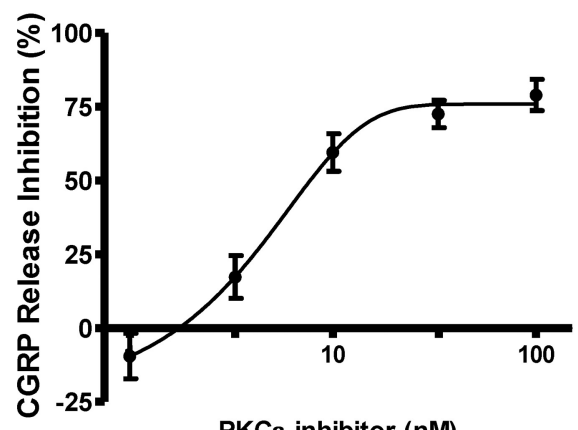

B

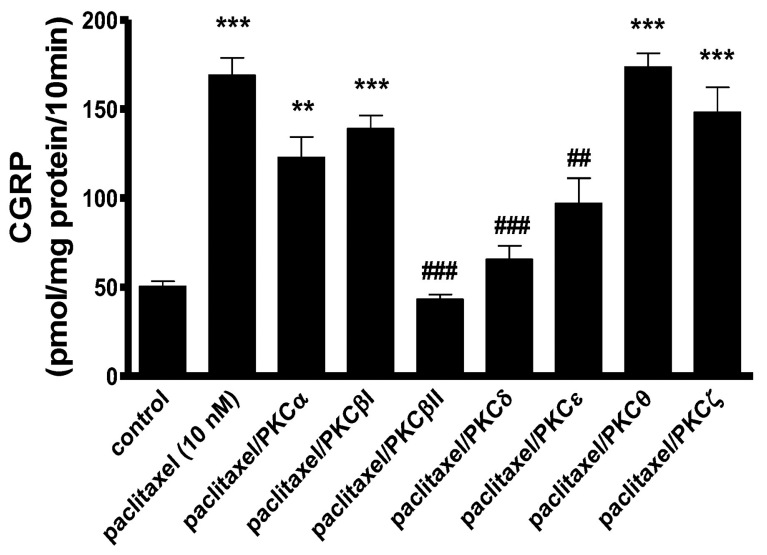

D

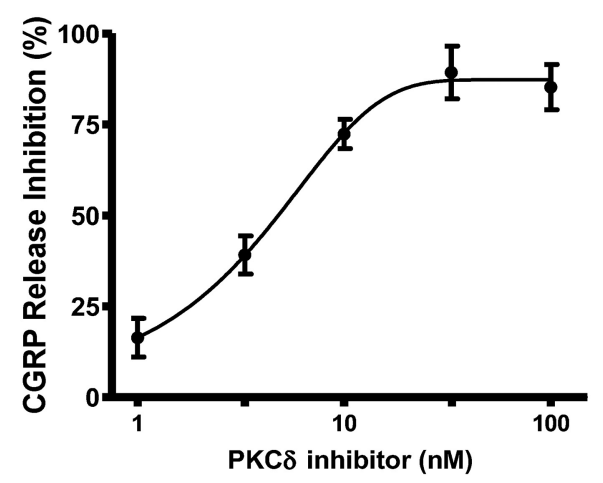

$\mathbf{F}$

\begin{tabular}{cccc}
\hline PKC & $\mathbf{I C}_{\mathbf{5 0}}(\mathbf{n M})$ & $\mathbf{E m a x}$ & $\mathbf{R}^{\mathbf{2}}$ \\
\hline $\boldsymbol{\beta} \mathbf{I I}$ & $4.153 \pm 1.175$ & $100.0 \pm 5.855$ & 0.93 \\
\hline $\boldsymbol{\delta}$ & $9.089 \pm 1.764$ & $87.29 \pm 4.039 \S \S$ & 0.92 \\
\hline $\boldsymbol{\varepsilon}$ & $4.059 \pm 1.369$ & $75.89 \pm 4.484^{\S \S \S \uparrow}$ & 0.93 \\
\hline
\end{tabular}

Figure 4. A, Dose-dependent release of CGRP produced by nanomolar concentrations of paclitaxel in the DRG neurons. $\boldsymbol{B}$, Inhibition of PKC $\beta \| l$, PKC $\delta$, and PKC $\epsilon$, but not other isoforms, significantly reduced the release of CGRP induced by paclitaxel. Individual myristoylated peptide inhibitor of PKC isoforms $(10 \mu \mathrm{M})$ was preincubated with DRG cells for 10 min and present throughout the 10 min incubation for release assay. ${ }^{* *} p<0.01,{ }^{* * *} p<0.001$ versus the control group; \#\#p<0.01 versus the paclitaxel group $(n=3)$. $C-F$, Dose-response curves and analysis of the inhibitors of $\operatorname{PKC} \beta \|$, PKC $\delta$, and PKC $\epsilon$ on the suppression of paclitaxel-induced CGRP release $(n=3) . \mathrm{I}_{50}$ and $E_{\max }$ for each inhibitor were determined based on the dose-response curve. $\S \S p<0.01, \S \S \S p<0.001$ versus the " $\beta \|$ " group; $\uparrow \uparrow p<0.01$ versus the " $\delta$ " group.

(Table 1). For PKC $\beta I I$, the ratio of fluorescent densities (plasma membrane vs cytosol) in paclitaxel-treated mice $(6.7 \pm 1.7)$ was significantly reduced after the spinal administration of the PKC $\beta$ II inhibitor $(1.6 \pm 0.3, p<0.01)$, which was comparable to the ratio in the control mice $(1.3 \pm 0.2)$. Similarly, the PKC $\delta$ inhibitor completely blocked the plasma membrane enrichment of PKC $\delta$ in paclitaxel-treated mice. The enhanced fluorescent density ratio (membrane/cytosol) of nociceptor PKC $\delta$ (5.2 \pm 1.6) was suppressed by the PKC $\delta$ inhibitor $(1.4 \pm 0.3$; not significantly different from the control) to the level found in the con- trol mice $(0.9 \pm 0.1)$. The PKC $\epsilon$ inhibitor also significantly reversed the membrane localization of PKC $\epsilon$ in paclitaxel-treated mice. In the DRG slices examined, the membrane/cytosol ratio of $\mathrm{PKC} \epsilon$, which was $1.1 \pm 0.1$ in the control mice, was increased to $3.5 \pm 0.5$ in paclitaxel-treated mice, and was restored to $1.5 \pm 0.7$ upon treatment with the PKC $\epsilon$ inhibitor. These data demonstrated that spinal administration of isoform-selective inhibitors of PKC $\beta$ II, PKC $\delta$, or PKC $\epsilon$ effectively blocked the activation of corresponding nociceptor $\mathrm{PKC}$ isoforms in the paclitaxel-treated mice. 
A
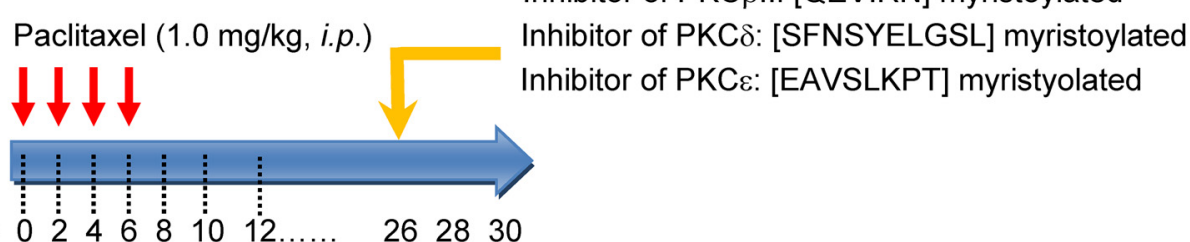

B DRG
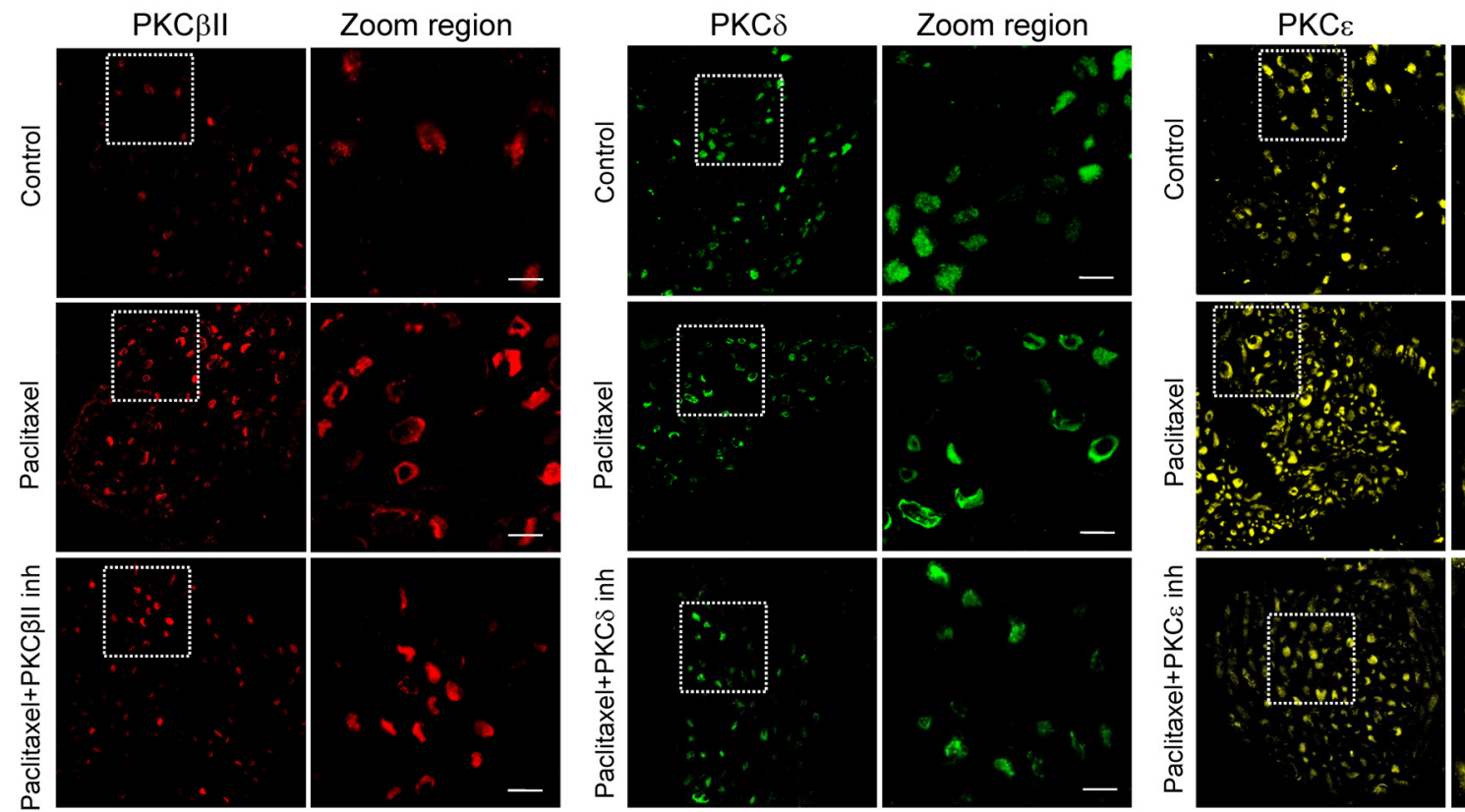

Zoom region

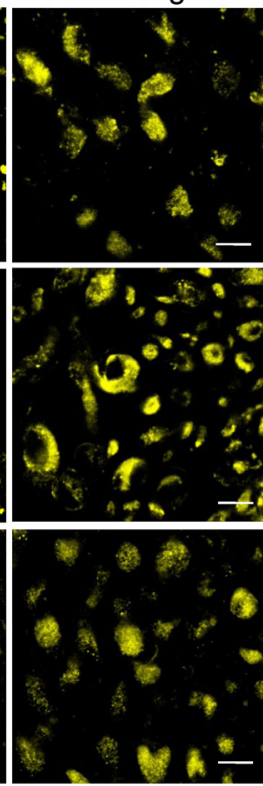

Figure 5. Activation of PKC $\beta$ II, PKC $\delta$, and PKC $\epsilon$ in primary afferent neurons in a mouse model of PIPN. $\boldsymbol{A}$, PIPN was induced by paclitaxel (1 mg/kg, i.p.; every other day for 4 treatments in ICR mice). Isoform-selective inhibitors of PKC $\beta \|$ ( $3.0 \mathrm{nmole})$, PKC $\delta$ ( $3.0 \mathrm{nmole})$, and PKC $\epsilon$ (1.6 nmole) were administered intrathecally on day $26 . \boldsymbol{B}$, Paclitaxel-induced plasma membrane translocation of PKC $\beta \|$, PKC $\delta$, and PKC $\epsilon$ was present in DRG neurons, which was significantly abolished 30 min after spinal administration of the PKC isoform inhibitors, respectively (bottom). Scale bar, $20 \mu \mathrm{m}$.

Table 1. Ratio of immunofluorescent density (plasma membrane/cytosol) for PKC isoforms

\begin{tabular}{llll}
\hline & PKC $\beta \|$ & PKC $\delta$ & PKC $\epsilon$ \\
\hline Control & $1.3 \pm 0.2$ & $0.9 \pm 0.1$ & $1.1 \pm 0.1$ \\
Paclitaxel & $6.7 \pm 1.7^{* * *}$ & $5.2 \pm 1.6^{* *}$ & $3.5 \pm 0.5^{* *}$ \\
Paclitaxel + PKC isoform inhibitor & $1.6 \pm 0.3 \# \#$ & $1.4 \pm 0.3 \# \#$ & $1.5 \pm 0.7 \# \#$ \\
\hline
\end{tabular}

$n=54$ (6 cells/slide, 3 DRG slides/mouse, 3 mice/group) were analyzed.

${ }^{* *} p<0.01,{ }^{* * *} p<0.001$ compared with the control group; \#\#p $<0.01$ compared with the paclitaxel group.

Participation of PKC $\beta I I$, PKC $\delta$, and PKC $\epsilon$ in paclitaxelinduced evoked sensory hypersensitivity

To investigate a causative role of PKC $\beta \mathrm{II}, \mathrm{PKC} \delta$, and PKC $\epsilon$ in paclitaxel-induced pain, we further examined whether inhibition of these isoforms can affect pain manifestations in PIPN. As expected, paclitaxel-treated mice exhibited fully developed hypersensitivity to mechanical probing by von Frey filament and to the noxious thermal stimulus applied to the left hindpaw on day 26 (Fig. 6). The PKC $\beta I I$ inhibitor (3.0 and 1.0 nmole, i.t.) significantly reversed paclitaxel-induced mechanical allodynia and heat hyperalgesia, whereas the inhibitor at a lower dose $(0.3 \mathrm{nmole})$ was ineffective (Fig. $6 A, B$ ). The peak effect was found at $2 \mathrm{~h}$ and lasted at least $4 \mathrm{~h}$. These data demonstrate that the dosedependent anti-allodynic/anti-hyperalgesic actions produced by the PKC $\beta$ II inhibitor correlated with its effective inhibition of nociceptor PKC $\beta I I$ in paclitaxel-treated mice (Fig. $5 B$ ).

After the intrathecal administration of the PKC $\delta$ inhibitor (1.0 and 3.0 nmole), hypersensitivities to the mechanical and thermal stimuli were significantly attenuated in a dose- and time-dependent manner in the paclitaxel-treated mice. The effects of PKC $\delta$ inhibitor lasted at least $4 \mathrm{~h}$ (Fig. $6 C, D$ ). As shown above, the PKC $\delta$ inhibitor blocked the activation of nociceptor PKC $\delta$ in PIPN (Fig. 5B).

We also performed mechanical and thermal sensitivity tests before and after the administration of the PKC $\epsilon$ inhibitor (0.6, 1.0 , and 1.6 nmole, i.t.). The mechanical allodynia and heat hyperalgesia induced by paclitaxel were significantly attenuated by the PKC $\epsilon$ inhibitor (1.0 and $1.6 \mathrm{nmole}$ ), whereas the lowest dose was minimally effective (Fig. $6 E, F$ ). Alleviation of mechanical allodynia by inhibiting PKC $\epsilon$ is in agreement with previous reports in rat (Dina et al., 2001) and mouse (Chen et al., 2011) models of PIPN. In this study, we found that the same inhibitory effects on evoked pain behaviors can be achieved by inhibiting $\mathrm{PKC} \delta$ and PKC $\beta$ II in PIPN. None of the PKC $\beta$ II, PKC $\delta$, and $\mathrm{PKC} \epsilon$ inhibitors used altered mechanical and thermal sensitivity in control animals (data not shown).

\section{Contribution of nociceptor PKC $\beta \mathrm{II}$ and PKC $\delta$, but not}

$\mathrm{PKC} \epsilon$, in paclitaxel-induced spontaneous pain

Patients with PIPN experience spontaneous pain. This has not been studied in rodent models of PIPN. Recently, we validated the use of negative reinforcement to detect spontaneous or ongoing pain in mice with persistent tissue or nerve injuries (He et al., 2012; Corder et al., 2013). In these animals, non-rewarding analgesics (e.g., lidocaine) can elicit CPP. In this study, we applied the CPP testing paradigm to determine whether spontane- 
A

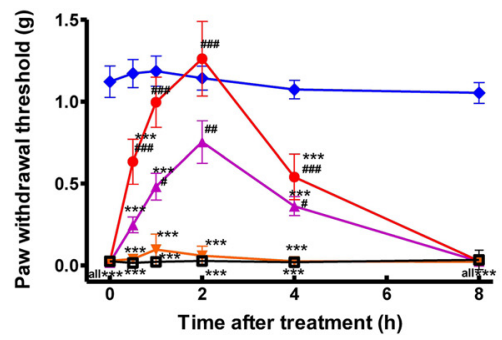

$\neg$ Control

* Paclitaxel

* Paclitaxel+PKC $\beta \|$ Inhibitor (0.3nmol)

\ Paclitaxel+PKC $\beta \|$ Inhibitor (1.0nmol)

B

$\rightarrow$ Paclitaxel+PKCß II Inhibitor (3.0nmol)

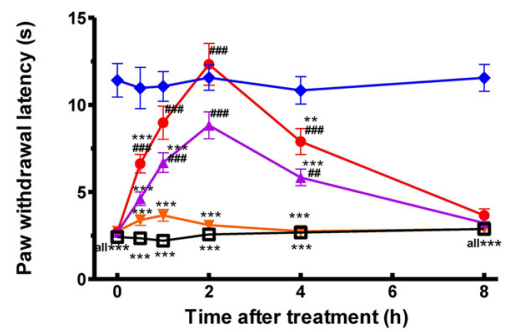

C

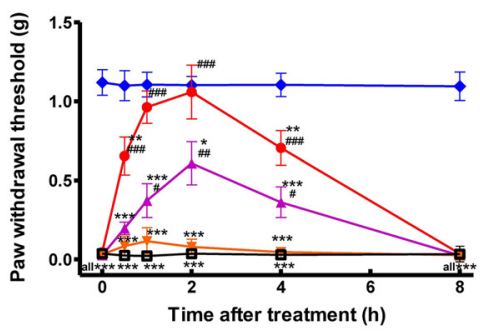

$\rightarrow$ Control

$\rightarrow$ Paclitaxel

* Paclitaxel+PKC $\delta$ Inhibitor $(0.3 \mathrm{nmol})$

- Paclitaxel+PKC $\delta$ Inhibitor (1.0nmol)

$\rightarrow$ Paclitaxel+PKC Inhibitor (3.0nmol)

D

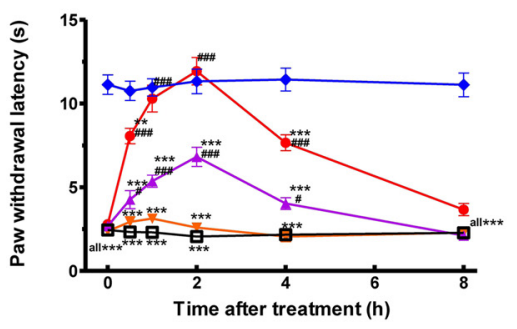

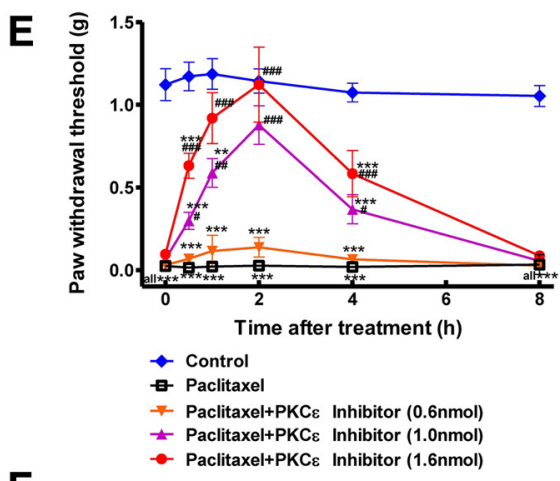

$\mathbf{F}$

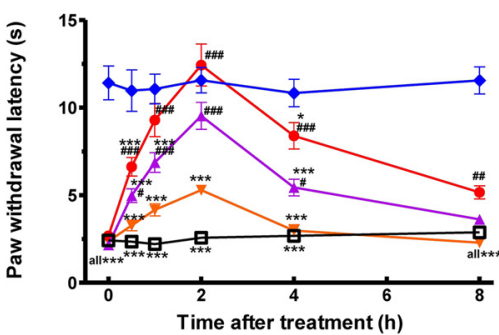

Figure 6. Dose- and time-dependent attenuation of mechanical and thermal hypersensitivity by the inhibitors of $\operatorname{PKC} \beta \|(\boldsymbol{A}, \boldsymbol{B}), \operatorname{PKC} \delta(\boldsymbol{C}, \boldsymbol{D})$, and $\operatorname{PKC} \in(\boldsymbol{E}, \boldsymbol{F})$ in PIPN. The paw withdrawal threshold to von Frey filament probing $(\boldsymbol{A}, \boldsymbol{C}, \boldsymbol{E})$ and withdrawal latency to radiant heat $(\boldsymbol{B}, \boldsymbol{D}, \boldsymbol{F})$ were measured before $(0)$ and $0.5,1,2,4$, and $8 \mathrm{~h}$ after the injection of PKC inhibitors (in $5 \mu$ l of saline, i.t.). ${ }^{*} p<0.05,{ }^{* *} p<0.01$, ${ }^{* *} p<0.001$ versus the control group; $\# p<0.05$, \#\#p $<0.01$, \#\#\#p<0.001 versus the paclitaxel group; $n=8$ for each group.

ous pain was present in mice with PIPN. After $3 \mathrm{~d}$ of preconditioning, control or paclitaxel-treated mice were paired with randomly chosen chambers after receiving saline $(5 \mu$ l, i.t., time 0 ) and lidocaine $(0.04 \%$, i.t., time $4 \mathrm{~h}$ ), and tested $20 \mathrm{~h}$ later (time $24 \mathrm{~h}$ ) for chamber preference. Paclitaxel-treated mice spent significantly more time in the lidocaine-paired chamber $(362 \pm$ $20 s)$ than in the saline-paired chamber $(300 \pm 14 s, p<0.05$; Fig. $7 A)$. Analysis of difference scores indicated that lidocaine generated $\mathrm{CPP}$ in the paclitaxel-treated mice, but not in the control mice (Fig. 7B). These data demonstrated for the first time that PIPN was accompanied by non-evoked spontaneous pain in mice.

The next question was whether PKC $\beta \mathrm{II}, \mathrm{PKC} \delta$, and $\mathrm{PKC} \epsilon$ were involved in paclitaxel-induced spontaneous pain. Instead of lidocaine, the inhibitor of $\mathrm{PKC} \beta \mathrm{II}, \mathrm{PKC} \delta$, or PKC $\epsilon$ was given intrathecally to the mice in the CPP test. If spontaneous pain is mediated by a PKC isoform, it is expected that inhibiting the isoform by its inhibitor will suppress spontaneous pain and produce CPP in paclitaxel-treated mice. When control or paclitaxeltreated mice were paired with the PKC $\beta I$ In inhibitor ( 3.0 nmole, i.t.) for $30 \mathrm{~min}$, paclitaxel-treated mice showed a strong preference for the PKC $\beta I I$ inhibitor-paired chamber $(537 \pm 43 \mathrm{~s}$ ) over the saline chamber $(205 \pm 20 \mathrm{~s}, p<0.001$; Fig. $7 C)$. In contrast, control mice spent similar amount of time in the saline chamber $(355 \pm 24 s)$ and the inhibitor-paired chamber $(337 \pm 35 s ; p>$ $0.05)$. Supported by the significant difference score $(p<0.001$; Fig. $7 D$ ), these data indicate that $\mathrm{PKC} \beta \mathrm{II}$ is a critical mediator for paclitaxel-induced spontaneous pain behavior.

Similarly, we studied the role of PKC $\delta$ in the mouse model of PIPN. After being paired with the PKC $\delta$ inhibitor $(3.0$ nmole, i.t.), paclitaxel-treated mice spent significantly more time in the PKC $\delta$ inhibitor-paired chamber $(419 \pm 18 \mathrm{~s})$ than in the saline chamber $(278 \pm 20 s ; p<0.001$; Fig. $7 E)$. Control mice did not show preference for the saline- (337 $\pm 26 \mathrm{~s})$ or the PKC $\delta$-paired $(326 \pm 16 s)$ chambers $(p>0.05)$. The difference score analysis confirmed that paclitaxel-treated mice exhibited CPP to the PKC $\delta$ inhibitor (Fig. $7 F$ ), indicating that PKC $\delta$ is important for spontaneous pain in addition to its role for evoked pain behaviors in PIPN.

We further determined whether the PKC $\epsilon$ inhibitor also produced CPP in paclitaxel-treated mice. Surprisingly, both control and paclitaxel-treated mice spent similar amount of time in the saline-paired and the PKC $\epsilon$ inhibitor-paired chambers (Fig. $7 G, H, p>0.05$ ), suggesting that spinal administration of the $\mathrm{PKC} \epsilon$ inhibitor (1.6 nmole) did not attenuate spontaneous pain in PIPN.

\section{Discussion}

Induction of painful peripheral neuropathy is a detrimental side effect limiting the effectiveness of chemotherapies such as taxanes. There has been widespread interest in understanding the mechanisms by which chemotherapeutic agents produce long-lasting painful neuropathy. We studied the nociceptor PKC isoforms in a mouse model of PIPN. We have identified PKC $\beta I$ and PKC $\delta$ as two new signaling mechanisms important for PIPN. Our data further support the role of PKC $\epsilon$ in PIPN, which was originally proposed by Levine and colleagues (Dina et al., 2001; Chen et al., 2011).

To guide the in vivo studies, we first took advantage of primary culture of DRG neurons, simulating their native conditions in which neurons are bathed in chemical milieu including NGF (Levi-Montalcini and Angeletti, 1968). Like all cellular models, this primary culture is not without limitations nor is it an exact replicate of in vivo conditions (Wang and Wang, 2003). Therefore, it is important that key findings are also studied in an in vivo model of PIPN that serves as the ultimate validation for in vitro data. Nonetheless, systematic profiling the entire family of PKC isoforms expressed in DRG neurons using a PKC translocation/ activation scan yielded three PKC isoforms that are activated by paclitaxel. The results were subsequently confirmed in the mouse model of PIPN, illustrating the utility and power of the in vitro model in guiding in vivo studies. Most importantly, we were able 
A

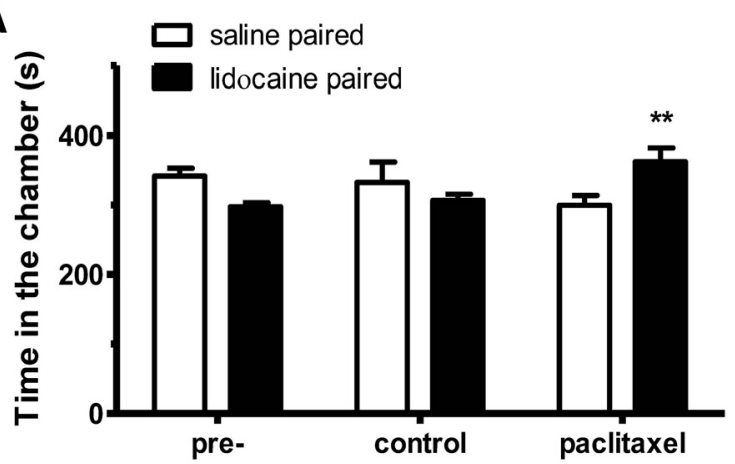

C

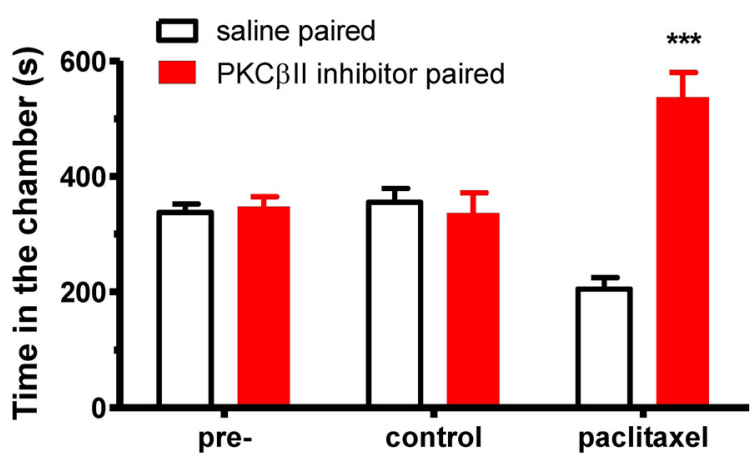

E

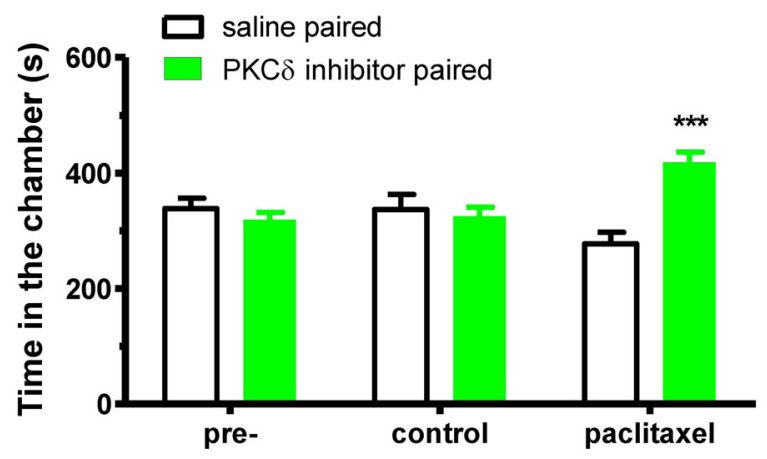

G

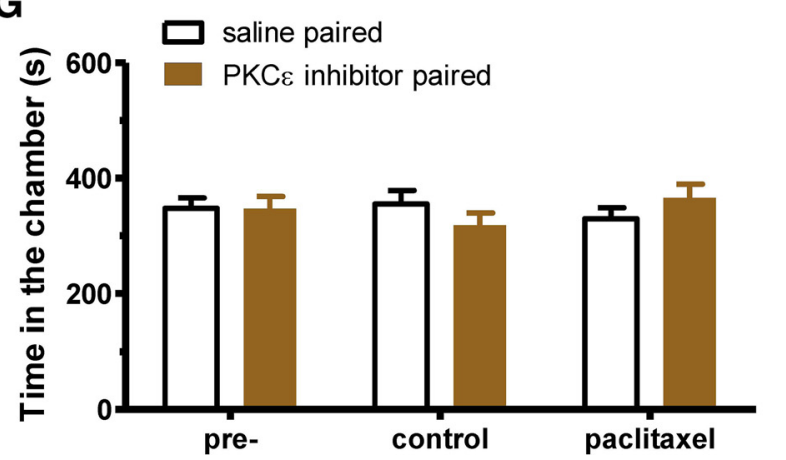

B

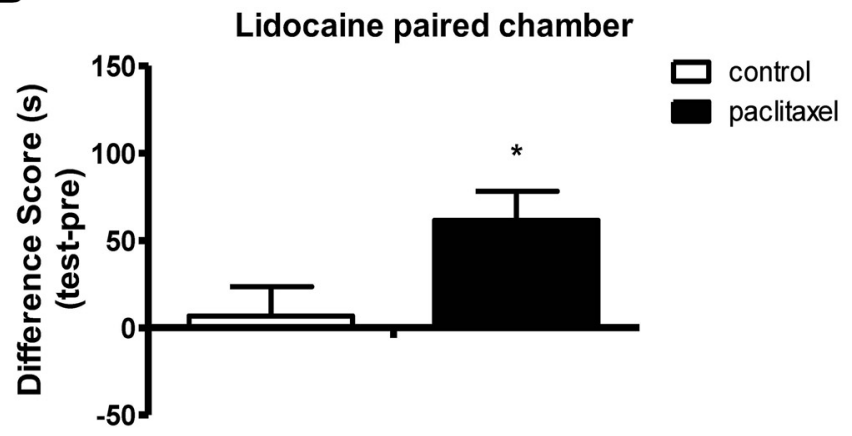

D

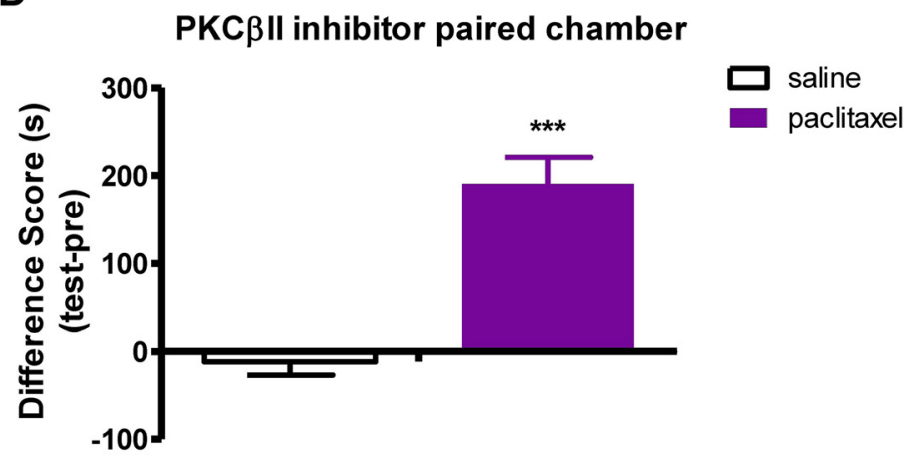

F

PKC\& inhibitor paired chamber

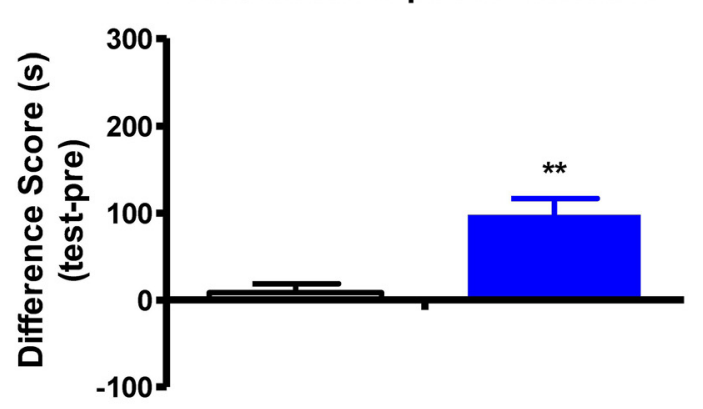

H

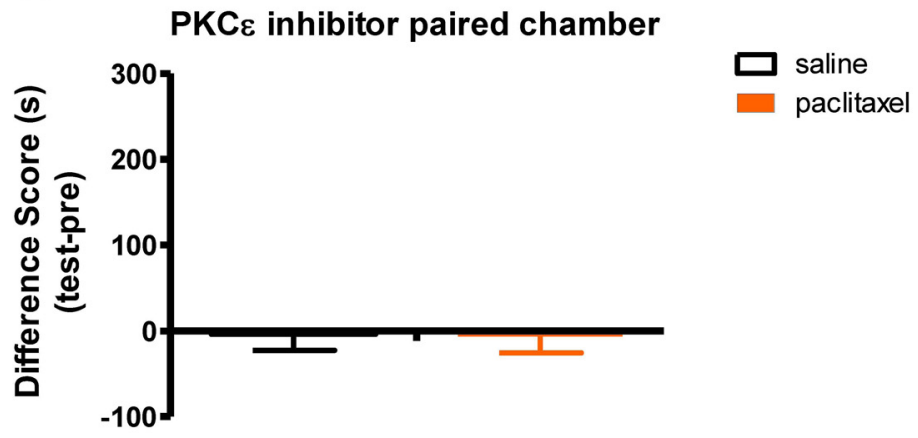

Figure 7. $A$, Lidocaine $(0.04 \%$ in $5 \mu$ l of saline, i.t.) induced CPP in paclitaxel-treated mice. Paclitaxel mice spent significantly more time in the lidocaine-paired chamber, whereas control mice showed no chamber preference. $\boldsymbol{B}$, Difference scores confirmed that paclitaxel-treated mice but not control mice showed CPP to lidocaine. $\boldsymbol{C}, \boldsymbol{E}$, Inhibitors of PKC $\beta$ II (3.0 nmole in $5 \mu \mathrm{l}$ of saline, i.t.) and PKC $\delta$ ( 3.0 nmole in $5 \mu \mathrm{l}$ of saline, i.t.) produced CPP in paclitaxel mice. Paclitaxel-treated mice spent significantly more time in the inhibitor-paired chamber, whereas control mice showed no chamber preference. $\boldsymbol{D}, \boldsymbol{F}$, Difference scores confirmed that paclitaxel-treated mice, but not control mice, showed CPP to inhibitors of PKC $\beta \|$ and PKC $\delta$. G, PKC $\epsilon$ inhibitor ( $1.6 \mathrm{nmole}$ in $5 \mu$ l of saline, i.t.) did not produce CPP in paclitaxel or control mice. Paclitaxel-treated mice and control mice showed no chamber preference, spending similar amount of time in saline- and PKC $\epsilon$ inhibitor-paired chambers. $\boldsymbol{H}$, Difference scores confirmed the absence of chamber preference. ${ }^{*} p<0.05$; ${ }^{* *} p<0.01 ;{ }^{* * *} p<$ $0.001 ; n=8$ for each group. 
to replicate the previous findings on PKCE (Dina et al., 2001; Chen et al., 2011). An earlier attempt by another group, which used high concentrations of paclitaxel $(10 \mu \mathrm{M})$, failed to identify activation of PKC $\epsilon$ by paclitaxel (Miyano et al., 2009). Previously, we found that paclitaxel at low concentrations (1-10 nM) triggered intercellular $\mathrm{Ca}^{2+}$ signaling (He and Wang, 2010). In the present study, we confirmed that paclitaxel exhibited its maximum effect on stimulating CGRP release at $10 \mathrm{~nm}$ (Fig. 4). Moreover, our study implicated for the first time the potential roles of PKC $\beta I$ II and PKC $\delta$ in PIPN.

The PKC family members are protein kinases with activity that depends on phospholipid, diacylglycerol, and in some cases $\mathrm{Ca}^{2+}$ (Parker et al., 1989; Steinberg, 2008). Individual PKC isoform appears to be restricted to particular cellular sites at resting conditions. Upon stimulation, PKC isoforms translocate to new subcellular sites such as the plasma membrane (Shoji et al., 1986), cytoskeletal element (Papadopoulos and Hall, 1989), and nucleus (Cambier et al., 1987) to ensure preferential and rapid phosphorylation of their substrates. Plasma membrane translocation by receptors for activated C-kinases (RACKs) could trigger the activation of a variety of channels, increase of $\mathrm{Ca}^{2+}$ influx, and release of excitatory neurotransmitters (Hucho et al., 2012; Joseph et al., 2013). Moreover, PKC isoforms remain activated even after the original activation signal or the $\mathrm{Ca}^{2+}$ wave has subsided (Nelsestuen and Bazzi, 1991). The long-lasting activation provides them the capability to contribute to long-term modulation of synaptic functions and act broadly to regulate multiple neuronal events including development, differentiation, and plasticity. Indeed, nociceptor PKC $\beta$ II, PKC $\delta$, and $\mathrm{PKC} \epsilon$ were still activated $20 \mathrm{~d}$ after the last injection of paclitaxel (Fig. 5B). Additional mechanisms may also contribute to the persistent activation of these PKC isoforms. We found that DRG neurons with paclitaxel-induced PKC translocation were also TRPV1-positive (Fig. 2C). TRPV1 activation can modulate excitatory synaptic transmission at the sensory synapse and its effects can be further augmented by activation of PKC (Sikand and Premkumar, 2007; Medvedeva et al., 2008). This feedforward loop provides another mechanism for the sustained activation of PKC isoforms that can contribute to persistent hyperalgesia in PIPN. A similar feedforward interaction may exist between PKC isoforms and the NMDA receptor (Wang and Wang, 2003). Activation of PKC $\beta I$, $\mathrm{PKC} \delta$, and $\mathrm{PKC} \epsilon$ can serve as critical second messengers for additional cellular events (e.g., new protein synthesis) to further maintain long-lasting PIPN (Brager et al., 2003).

To determine a causative role of individual PKC isoform in paclitaxel-induced pain, we used isoform-specific PKC inhibitors. The isoform selectivity has been previously established in vitro (Chen and Mochly-Rosen, 2001; Stebbins and Mochly-Rosen, 2001; Braun and Mochly-Rosen, 2003) and in vivo (Bright et al., 2004; Burkey et al., 2004; Tanaka et al., 2004). These inhibitors selectively disrupt the interaction between each PKC isoform and its corresponding RACK, preventing the translocation and activation of the corresponding PKC isoform without affecting the others (Mochly-Rosen, 1995; Souroujon and Mochly-Rosen, 1998).

After in vitro CGRP release studies, we confirmed in a mouse model of PIPN that spinal administration of the PKC $\beta$ II, PKC $\delta$, or PKC $\epsilon$ inhibitor effectively inhibited its corresponding PKC isoform in the DRG neurons and attenuated the evoked pain manifestations in vivo. PKC $\epsilon$ has been implicated previously in PIPN (Dina et al., 2001; Chen et al., 2011), as well as several other pain conditions (Sachs et al., 2009; Joseph and Levine, 2010; Pan et al., 2010). PKC $\epsilon$ can phosphorylate TRPV1 on Ser502 and Ser800, which potentiates capsaicin-induced depolarization in affer- ent neurons (Zhou et al., 2001; Numazaki et al., 2002; Mandadi et al., 2006). More importantly, hyperalgesia priming is found to be PKC $\epsilon$ dependent (Parada et al., 2005; Ferrari et al., 2013). PKC $\epsilon$ in the primary afferent nociceptor induces a switch in intracellular signaling pathways mediating cytokine-induced nociceptor activation, which could serve as a neuronal plastic mechanism responsible for the functional transition of pain states from acute to chronic (Reichling and Levine, 2009). This is the first study that has implicated a functional role of PKC $\beta \mathrm{II}$ and $\mathrm{PKC} \delta$ in paclitaxel-induced persistent pain. Whether PKC $\beta I$ and $\mathrm{PKC} \delta$ have similar roles in pain transition remains to be studied.

Inhibition of any one of the three PKC isoforms is sufficient to reverse paclitaxel-induced mechanical allodynia and heat hyperalgesia (Fig. 6), suggesting that all three isoforms are required for the expression of evoked pain. The exact mechanisms of their participations in the evoked pain component of PIPN are unclear. PKC activation may be one of the initial steps in a cascade of signaling events leading to long-term plasticity in the persistent pain condition (Ganguly et al., 2000; Velázquez et al., 2007). Since current study is focused on establishing PKC isoforms important for PIPN, future research is needed to identify downstream effectors of PKC and upstream mechanisms for their activation in PIPN. Activation of PKC $\beta I$ I by intracellular $\mathrm{Ca}^{2+}$ is a logical mechanism for its activation. Others have found a role of Epac in the activation of PKC $\epsilon$ (Hucho et al., 2005). In addition, novel PKCs that do not require $\mathrm{Ca}^{2+}$ for activation can still be activated when there is an increase in intracellular $\mathrm{Ca}^{2+}$ (Larsen et al., 2000; Shah et al., 2005; Zhou et al., 2006; Hui et al., 2014). For the downstream effectors, several TRP channels have been indicated to mediate signaling from PKC in persistent pain conditions (Alessandri-Haber et al., 2009), including PIPN (Chen et al., 2011).

The present study demonstrated for the first time the presence of sustained spontaneous pain behaviors in mice with PIPN. This intriguing finding could potentially address a major disconnection between current understanding of PIPN in basic research and clinical observation that patients describe their pain as continuous and ongoing, whereas the limited basic research has focused only on evoked pain. Both PKC $\beta \mathrm{II}$ and $\mathrm{PKC} \delta$ were found to be important for spontaneous pain behaviors in PIPN. The PKC $\beta$ II inhibitor produced a higher difference score than the $\mathrm{PKC} \delta$ inhibitor, suggesting that PKC $\beta \mathrm{II}$ may have a greater influence on spontaneous pain in PIPN.

On the contrary, PKC $\epsilon$ did not appear to contribute to spontaneous pain in PIPN. It is unclear why there was no detectable effect on spontaneous pain by inhibiting nociceptor PKC $\epsilon$, although the PKC $\epsilon$ inhibitor was effective in blocking paclitaxelinduced activation of nociceptor PKC $\epsilon$ (Fig. 5). PKC $\epsilon$ signaling in primary afferent nociceptors is known to depend on cytoskeleton and cell membrane microdomains (Hucho and Levine, 2007). It has been proposed that PKC $\epsilon$ modulates nociception through its activation of the TRPV1 receptor. PKC $\epsilon$ phosphorylation of TRPV1 at Ser800 hindered microtubule-TRPV1 binding, which is essential for estrogen-induced and PKC $\epsilon$-dependent mechanical pain sensitization and microtubule disassembly (Goswami et al., 2011). As a microtubule stabilizer, paclitaxel may block this specific downstream signaling pathway of PKC $\epsilon$. Our data, however, did not preclude PKC $\epsilon$ in other locations that can still modulate spontaneous pain, presumably at a location where the PKC $\epsilon$ inhibitor, given intrathecally, cannot access or reach sufficient concentrations.

In summary, by focusing on nociceptor PKC isoforms and their mediation of pain response, we performed a comprehensive analysis of individual PKC isoform in PIPN. PKC $\beta \mathrm{II}, \mathrm{PKC} \delta$, and 
PKC $\epsilon$ were found to be activated by low concentrations of paclitaxel. Inhibiting $\mathrm{PKC} \beta \mathrm{II}, \mathrm{PKC} \delta$, and $\mathrm{PKC} \epsilon$, but not other PKC isoforms, attenuated paclitaxel-induced release of CGRP from primary afferent sensory neurons. By delineating their functional involvement in pain behaviors in mice with PIPN, we found that $\mathrm{PKC}$ isoforms differentially mediate paclitaxel-induced ongoing spontaneous pain and evoked pain, which could provide new information for designing pharmacological therapies to prevent or treat chemotherapy-induced painful neuropathies.

\section{References}

Alessandri-Haber N, Dina OA, Chen X, Levine JD (2009) TRPC1 and TRPC6 channels cooperate with TRPV4 to mediate mechanical hyperalgesia and nociceptor sensitization. J Neurosci 29:6217-6228. CrossRef Medline

Amadesi S, Cottrell GS, Divino L, Chapman K, Grady EF, Bautista F, Karanjia R, Barajas-Lopez C, Vanner S, Vergnolle N, Bunnett NW (2006) Protease-activated receptor 2 sensitizes TRPV1 by protein kinase Cepsilon- and A-dependent mechanisms in rats and mice. J Physiol 575: 555-571. CrossRef Medline

Barber LA, Vasko MR (1996) Activation of protein kinase C augments peptide release from rat sensory neurons. J Neurochem 67:72-80. Medline

Borsook D, Hargreaves R, Bountra C, Porreca F (2014) Lost but making progress-where will new analgesic drugs come from? Sci Transl Med 6:249sr3. CrossRef Medline

Brager DH, Cai X, Thompson SM (2003) Activity-dependent activation of presynaptic protein kinase $\mathrm{C}$ mediates post-tetanic potentiation. Nat Neurosci 6:551-552. CrossRef Medline

Braun MU, Mochly-Rosen D (2003) Opposing effects of delta- and zeta-protein kinase $\mathrm{C}$ isozymes on cardiac fibroblast proliferation: use of isozyme-selective inhibitors. J Mol Cell Cardiol 35:895-903. CrossRef Medline

Bright R, Raval AP, Dembner JM, Pérez-Pinzón MA, Steinberg GK, Yenari MA, Mochly-Rosen D (2004) Protein kinase C delta mediates cerebral reperfusion injury in vivo. J Neurosci 24:6880-6888. CrossRef Medline

Burkey TH, Hingtgen CM, Vasko MR (2004) Isolation and culture of sensory neurons from the dorsal-root ganglia of embryonic or adult rats. Methods Mol Med 99:189-202. Medline

Cambier JC, Newell MK, Justement LB, McGuire JC, Leach KL, Chen ZZ (1987) Ia binding ligands and cAMP stimulate nuclear translocation of PKC in B lymphocytes. Nature 327:629-632. CrossRef Medline

Chen C, Mochly-Rosen D (2001) Opposing effects of delta and xi PKC in ethanol-induced cardioprotection. J Mol Cell Cardiol 33:581-585. CrossRef Medline

Chen L, Hahn H, Wu G, Chen CH, Liron T, Schechtman D, Cavallaro G, Banci L, Guo Y, Bolli R, Dorn GW 2nd, Mochly-Rosen D (2001) Opposing cardioprotective actions and parallel hypertrophic effects of delta PKC and epsilon PKC. Proc Natl Acad Sci U S A 98:11114-11119. CrossRef Medline

Chen Y, Yang C, Wang ZJ (2010) Ca2+/calmodulin-dependent protein kinase II alpha is required for the initiation and maintenance of opioidinduced hyperalgesia. J Neurosci 30:38-46. CrossRef Medline

Chen Y, Yang C, Wang ZJ (2011) Proteinase-activated receptor 2 sensitizes transient receptor potential vanilloid 1 , transient receptor potential vanilloid 4, and transient receptor potential ankyrin 1 in paclitaxel-induced neuropathic pain. Neuroscience 193:440-451. CrossRef Medline

Corder G, Doolen S, Donahue RR, Winter MK, Jutras BL, He Y, Hu X, Wieskopf JS, Mogil JS, Storm DR, Wang ZJ, McCarson KE, Taylor BK (2013) Constitutive mu-opioid receptor activity leads to long-term endogenous analgesia and dependence. Science 341:1394-1399. CrossRef Medline

Dina OA, Chen X, Reichling D, Levine JD (2001) Role of protein kinase Cepsilon and protein kinase $\mathrm{A}$ in a model of paclitaxel-induced painful peripheral neuropathy in the rat. Neuroscience 108:507-515. CrossRef Medline

Dougherty PM, Cata JP, Cordella JV, Burton A, Weng HR (2004) Taxol-induced sensory disturbance is characterized by preferential impairment of myelinated fiber function in cancer patients. Pain 109:132-142. CrossRef Medline

Einzig AI, Wiernik PH, Sasloff J, Runowicz CD, Goldberg GL (1992) Phase II study and long-term follow-up of patients treated with taxol for advanced ovarian adenocarcinoma. J Clin Oncol 10:1748-1753. Medline

Ferrari LF, Bogen O, Levine JD (2013) Role of nociceptor alphaCaMKII in transition from acute to chronic pain (hyperalgesic priming) in male and female rats. J Neurosci 33:11002-11011. CrossRef Medline

Ganguly K, Kiss L, Poo M (2000) Enhancement of presynaptic neuronal excitability by correlated presynaptic and postsynaptic spiking. Nat Neurosci 3:1018-1026. CrossRef Medline

Goswami C, Kuhn J, Dina OA, Fernández-Ballester G, Levine JD, FerrerMontiel A, Hucho T (2011) Estrogen destabilizes microtubules through an ion-conductivity-independent TRPV1 pathway. J Neurochem 117: 995-1008. CrossRef Medline

Hargreaves K, Dubner R, Brown F, Flores C, Joris J (1988) A new and sensitive method for measuring thermal nociception in cutaneous hyperalgesia. Pain 32:77-88. CrossRef Medline

He Y, Wang Z (2010) Substance P release mediated by synchronized activation of PKA and PKC serves as a cellular mechanism of paclitaxel-induced persistent pain. Soc Neurosci Abstr 30:175.17.

He Y, Yang C, Kirkmire CM, Wang ZJ (2010) Regulation of opioid tolerance by let-7 family microRNA targeting the mu opioid receptor. J Neurosci 30:10251-10258. CrossRef Medline

He Y, Tian X, Hu X, Porreca F, Wang ZJ (2012) Negative reinforcement reveals non-evoked ongoing pain in mice with tissue or nerve injury. J Pain 13:598-607. CrossRef Medline

Horwitz SB (1992) Mechanism of action of taxol. Trends Pharmacol Sci 13:134-136. CrossRef Medline

Hucho T, Levine JD (2007) Signaling pathways in sensitization: toward a nociceptor cell biology. Neuron 55:365-376. CrossRef Medline

Hucho TB, Dina OA, Levine JD (2005) Epac mediates a cAMP-to-PKC signaling in inflammatory pain: an isolectin $\mathrm{B} 4(+)$ neuron-specific mechanism. J Neurosci 25:6119-6126. CrossRef Medline

Hucho T, Suckow V, Joseph EK, Kuhn J, Schmoranzer J, Dina OA, Chen X, Karst M, Bernateck M, Levine JD, Ropers HH (2012) Ca++/CaMKII switches nociceptor-sensitizing stimuli into desensitizing stimuli. J Neurochem 123:589-601. CrossRef Medline

Hui X, Reither G, Kaestner L, Lipp P (2014) Targeted activation of conventional and novel protein kinases $\mathrm{C}$ through differential translocation patterns. Mol Cell Biol 34:2370-2381. CrossRef Medline

Hylden JL, Wilcox GL (1980) Intrathecal morphine in mice: a new technique. Eur J Pharmacol 67:313-316. CrossRef Medline

Joseph EK, Levine JD (2010) Multiple PKCepsilon-dependent mechanisms mediating mechanical hyperalgesia. Pain 150:17-21. CrossRef Medline

Joseph EK, Green PG, Bogen O, Alvarez P, Levine JD (2013) Vascular endothelial cells mediate mechanical stimulation-induced enhancement of endothelin hyperalgesia via activation of $\mathrm{P} 2 \mathrm{X} 2 / 3$ receptors on nociceptors. J Neurosci 33:2849-2859. CrossRef Medline

Julius D, Basbaum AI (2001) Molecular mechanisms of nociception. Nature 413:203-210. CrossRef Medline

Larsen EC, DiGennaro JA, Saito N, Mehta S, Loegering DJ, Mazurkiewicz JE, Lennartz MR (2000) Differential requirement for classic and novel PKC isoforms in respiratory burst and phagocytosis in RAW 264.7 cells. J Immunol 165:2809-2817. CrossRef Medline

Lee JJ, Swain SM (2006) Peripheral neuropathy induced by microtubulestabilizing agents. J Clin Oncol 24:1633-1642. CrossRef Medline

Levi-Montalcini R, Angeletti PU (1968) Nerve growth factor. Physiol Rev 48:534-569. Medline

Lindsay RM (1988) Nerve growth factors (NGF, BDNF) enhance axonal regeneration but are not required for survival of adult sensory neurons. J Neurosci 8:2394-2405. Medline

Mandadi S, Tominaga T, Numazaki M, Murayama N, Saito N, Armati PJ, Roufogalis BD, Tominaga M (2006) Increased sensitivity of desensitized TRPV1 by PMA occurs through PKCepsilon-mediated phosphorylation at S800. Pain 123:106-116. CrossRef Medline

Medvedeva YV, Kim MS, Usachev YM (2008) Mechanisms of prolonged presynaptic $\mathrm{Ca} 2+$ signaling and glutamate release induced by TRPV1 activation in rat sensory neurons. J Neurosci 28:5295-5311. CrossRef Medline

Miyano K, Tang HB, Nakamura Y, Morioka N, Inoue A, Nakata Y (2009) Paclitaxel and vinorelbine, evoked the release of substance $\mathrm{P}$ from cultured rat dorsal root ganglion cells through different PKC isoformsensitive ion channels. Neuropharmacology 57:25-32. CrossRef Medline

Mochly-Rosen D (1995) Localization of protein kinases by anchoring proteins: a theme in signal transduction. Science 268:247-251. CrossRef Medline

Nelsestuen GL, Bazzi MD (1991) Activation and regulation of protein kinase $\mathrm{C}$ enzymes. J Bioenerg Biomembr 23:43-61. Medline

Nishizuka Y (1995) Protein kinase C and lipid signaling for sustained cellular responses. FASEB J 9:484-496. Medline

Numazaki M, Tominaga T, Toyooka H, Tominaga M (2002) Direct phosphoryla- 
tion of capsaicin receptor VR1 by protein kinase Cepsilon and identification of two target serine residues. J Biol Chem 277:13375-13378. CrossRef Medline

Pan HL, Zhang YQ, Zhao ZQ (2010) Involvement of lysophosphatidic acid in bone cancer pain by potentiation of TRPV1 via PKCepsilon pathway in dorsal root ganglion neurons. Mol Pain 6:85. CrossRef Medline

Papadopoulos V, Hall PF (1989) Isolation and characterization of protein kinase C from Y-1 adrenal cell cytoskeleton. J Cell Biol 108:553-567. CrossRef Medline

Parada CA, Reichling DB, Levine JD (2005) Chronic hyperalgesic priming in the rat involves a novel interaction between cAMP and PKCepsilon second messenger pathways. Pain 113:185-190. CrossRef Medline

Parker PJ, Kour G, Marais RM, Mitchell F, Pears C, Schaap D, Stabel S, Webster C (1989) Protein kinase C-a family affair. Mol Cell Endocrinol 65:1-11. CrossRef Medline

Perez EA, Vogel CL, Irwin DH, Kirshner JJ, Patel R (2001) Multicenter phase II trial of weekly paclitaxel in women with metastatic breast cancer. J Clin Oncol 19:4216-4223. Medline

Peters CM, Jimenez-Andrade JM, Jonas BM, Sevcik MA, Koewler NJ, Ghilardi JR, Wong GY, Mantyh PW (2007) Intravenous paclitaxel administration in the rat induces a peripheral sensory neuropathy characterized by macrophage infiltration and injury to sensory neurons and their supporting cells. Exp Neurol 203:42-54. CrossRef Medline

Pignata S, De Placido S, Biamonte R, Scambia G, Di Vagno G, Colucci G, Febbraro A, Marinaccio M, Lombardi AV, Manzione L, Cartenì G, Nardi M, Danese S, Valerio MR, de Matteis A, Massidda B, Gasparini G, Di Maio M, Pisano C, Perrone F (2006) Residual neurotoxicity in ovarian cancer patients in clinical remission after first-line chemotherapy with carboplatin and paclitaxel: the Multicenter Italian Trial in Ovarian cancer (MITO-4) retrospective study. BMC Cancer 6:5. CrossRef Medline

Postma TJ, Vermorken JB, Liefting AJ, Pinedo HM, Heimans JJ (1995) Paclitaxel-induced neuropathy. Ann Oncol 6:489-494. Medline

Reichling DB, Levine JD (2009) Critical role of nociceptor plasticity in chronic pain. Trends Neurosci 32:611-618. CrossRef Medline

Reichling DB, Green PG, Levine JD (2013) The fundamental unit of pain is the cell. Pain 154:S2-S9. CrossRef Medline

Rowinsky EK (1993) Clinical pharmacology of Taxol. J Natl Cancer Inst Monogr 25-37.

Sachs D, Villarreal C, Cunha F, Parada C, Ferreira Sh (2009) The role of PKA and PKCepsilon pathways in prostaglandin E2-mediated hypernociception. Br J Pharmacol 156:826-834. CrossRef Medline

Shah SA, Looby E, Volkov Y, Long A, Kelleher D (2005) Ursodeoxycholic acid inhibits translocation of protein kinase $\mathrm{C}$ in human colonic cancer cell lines. Eur J Cancer 41:2160-2169. CrossRef Medline
Shoji M, Girard PR, Mazzei GJ, Vogler WR, Kuo JF (1986) Immunocytochemical evidence for phorbol ester-induced protein kinase C translocation in HL60 cells. Biochem Biophys Res Commun 135:1144-1149. CrossRef Medline

Sikand P, Premkumar LS (2007) Potentiation of glutamatergic synaptic transmission by protein kinase C-mediated sensitization of TRPV1 at the first sensory synapse. J Physiol 581:631-647. CrossRef Medline

Smith FL, Gabra BH, Smith PA, Redwood MC, Dewey WL (2007) Determination of the role of conventional, novel and atypical PKC isoforms in the expression of morphine tolerance in mice. Pain 127:129-139. CrossRef Medline

Souroujon MC, Mochly-Rosen D (1998) Peptide modulators of proteinprotein interactions in intracellular signaling. Nat Biotechnol 16:919924. CrossRef Medline

Stebbins EG, Mochly-Rosen D (2001) Binding specificity for RACK1 resides in the V5 region of beta II protein kinase C. J Biol Chem 276:2964429650. CrossRef Medline

Steinberg SF (2008) Structural basis of protein kinase C isoform function. Physiol Rev 88:1341-1378. CrossRef Medline

Tanaka M, Terry RD, Mokhtari GK, Inagaki K, Koyanagi T, Kofidis T, MochlyRosen D, Robbins RC (2004) Suppression of graft coronary artery disease by a brief treatment with a selective epsilonPKC activator and a deltaPKC inhibitor in murine cardiac allografts. Circulation 110:II194-II199. Medline

Tulpule A, Groopman J, Saville MW, Harrington W Jr, Friedman-Kien A, Espina BM, Garces C, Mantelle L, Mettinger K, Scadden DT, Gill PS (2002) Multicenter trial of low-dose paclitaxel in patients with advanced AIDS-related Kaposi sarcoma. Cancer 95:147-154. CrossRef Medline

Velázquez KT, Mohammad H, Sweitzer SM (2007) Protein kinase C in pain: involvement of multiple isoforms. Pharmacol Res 55:578-589. CrossRef Medline

Wani MC, Taylor HL, Wall ME, Coggon P, McPhail AT (1971) Plant antitumor agents. VI. The isolation and structure of taxol, a novel antileukemic and antitumor agent from Taxus brevifolia. J Am Chem Soc 93:2325-2327. CrossRef Medline

Wang LX, Wang ZJ (2003) Animal and cellular models of chronic pain. Adv Drug Deliv Rev 55:949-965. CrossRef Medline

Zhou X, Yang W, Li J (2006) Ca2+- and protein kinase C-dependent signaling pathway for nuclear factor-kappaB activation, inducible nitricoxide synthase expression, and tumor necrosis factor-alpha production in lipopolysaccharide-stimulated rat peritoneal macrophages. J Biol Chem 281:31337-31347. CrossRef Medline

Zhou Y, Zhou ZS, Zhao ZQ (2001) PKC regulates capsaicin-induced currents of dorsal root ganglion neurons in rats. Neuropharmacology 41: 601-608. CrossRef Medline 